\title{
Ground Failure Triggered by Shaking during the November 30, 2018, Magnitude 7.1 Anchorage, Alaska, Earthquake
}

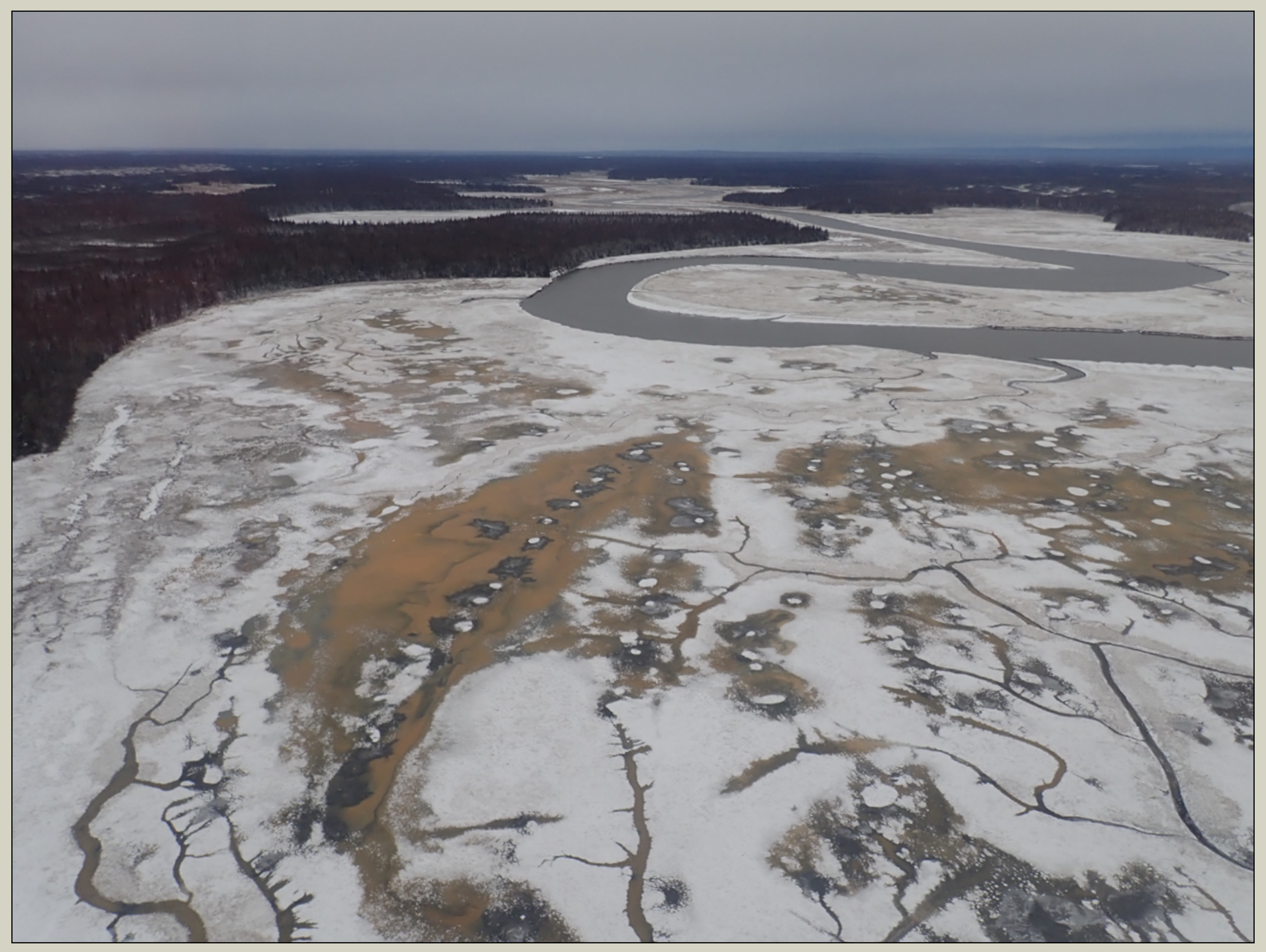

Open-File Report 2020-1043 
Cover. Photograph of a complex of sand boils along the mouth of the Little Susitna River, north of Anchorage, Alaska. 


\section{Ground Failure Triggered by Shaking during the November 30, 2018, Magnitude 7.1 Anchorage, Alaska, Earthquake}

By Alex R.R. Grant, Randall W. Jibson, Robert C. Witter, Kate E. Allstadt, Eric M. Thompson, and Adrian M. Bender

Open-File Report 2020-1043 


\title{
U.S. Department of the Interior DAVID BERNHARDT, Secretary
}

\author{
U.S. Geological Survey \\ James F. Reilly II, Director
}

\section{U.S. Geological Survey, Reston, Virginia: 2020}

For more information on the USGS - the Federal source for science about the Earth, its natural and living resources, natural hazards, and the environment-visit https://www.usgs.gov or call 1-888-ASK-USGS (1-888-275-8747).

For an overview of USGS information products, including maps, imagery, and publications, visit https://store.usgs.gov.

Any use of trade, firm, or product names is for descriptive purposes only and does not imply endorsement by the U.S. Government.

Although this information product, for the most part, is in the public domain, it also may contain copyrighted materials as noted in the text. Permission to reproduce copyrighted items must be secured from the copyright owner.

Suggested citation:

Grant, A.R.R., Jibson, R.W., Witter, R.C., Allstadt, K.E., Thompson, E.M., and Bender, A.M., 2020, Ground failure triggered by shaking during the November 30, 2018, magnitude 7.1 Anchorage, Alaska, earthquake: U.S. Geological Survey Open-File Report 2020-1043, 21 p., https://doi.org/10.3133/ofr20201043.

Associated data for this publication:

Grant, A.R.R., Jibson, R.W., Allstadt, K.E., Thompson, E.M., Witter, R.C., Bender, and A.M., Schmitt, R.G., 2020,

Ground failure triggered by shaking during the M7 Anchorage earthquake: U.S. Geological Survey data release, https://doi.org/10.5066/P990NUNM.

ISSN 2331-1258 (online) 


\section{Contents}

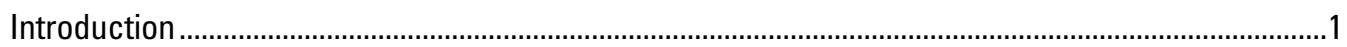

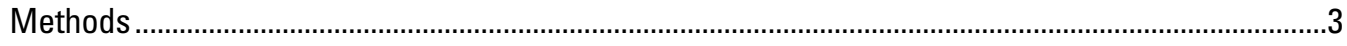

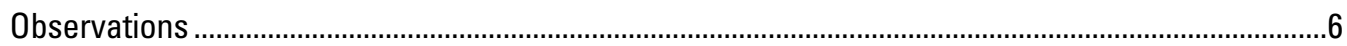

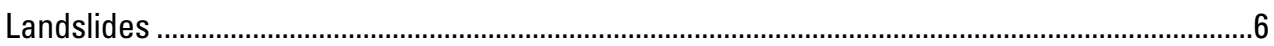

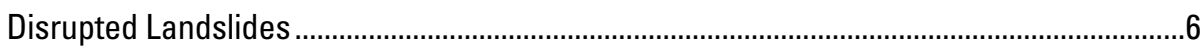

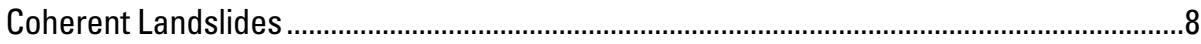

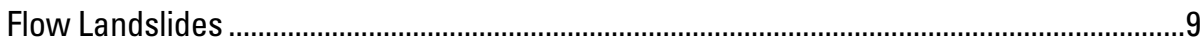

Landslides from the 1964 Alaska Earthquake ....................................................................12

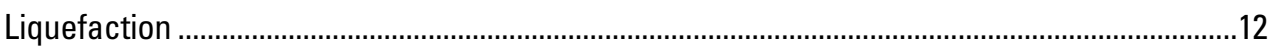

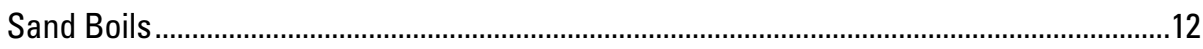

Extensional Cracks with Associated Sand Ejecta ................................................................14

Extensional Cracks without Associated Sand Ejecta ...........................................................14

Other Observations.............................................................................................................. 16

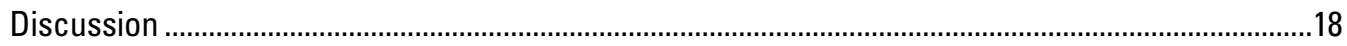

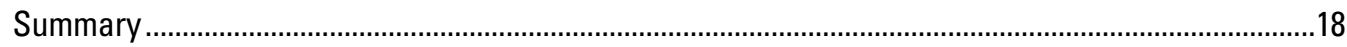

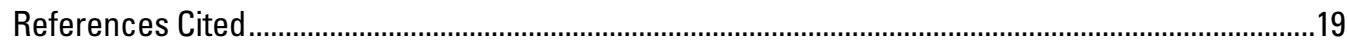

\section{Figures}

1. ShakeMap produced by the U.S. Geological Survey Alaska Earthquake Center of the Cook Inlet region, Alaska, for the magnitude 7.1 earthquake on November 30, 2018 ......2

2. Maps of estimated ground failure probabilities in the Cook Inlet region, Alaska, following the magnitude 7.1 Anchorage earthquake........................................................

3. Map of GPS tracks of field work in the Cook Inlet region, Alaska .....................................

4. Overview map showing locations of named places and images discussed in the text...5

5. Photograph of ground failure of an engineered fill-slope embankment ............................

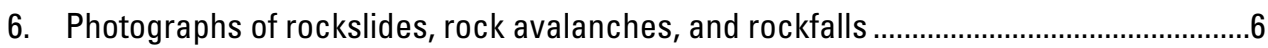

7. Photographs of disrupted landslides and coastal bluff collapses ....................................7

8. Digital terrain models derived from lidar data acquired before and after the 2018 Anchorage earthquake used to estimate elevation changes induced by slope failure along the Eagle River .......................................................................................................

9. Photographs of rockfalls and coastal bluff landslides ..................................................

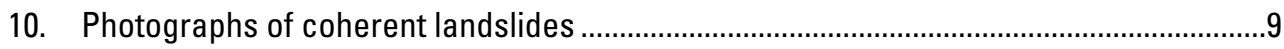

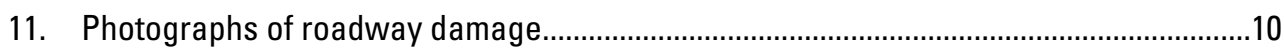

12. Photographs of the Potter Hill flow slides ...................................................................10

13. Digital terrain models derived from lidar data acquired before and after the 2018 Anchorage earthquake used to estimate elevation changes caused by the Potter Hill landslides

14. Photographs of minor cracking along 1964 landslide grabens in Anchorage .................13

15. Photograph of a complex of sand boils along the mouth of the Little Susitna River north of Anchorage ...... 
16. Photographs of sand boils and possible relict sand boils observed following the Anchorage earthquake

17. Photographs of evidence of liquefaction in Anchorage .............................................15

18. Photograph of extensional lateral-spread cracks on the north bank of the Knik River near the Old Glenn Highway ..........................................................................................15

19. Photographs of extensional lateral-spread cracks without obvious sand ejecta...........16

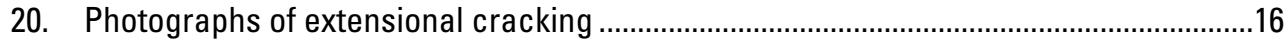

21. Photographs of examples of bank collapse following the Anchorage earthquake ........17

22. Photographs from Lower Fire Lake..........................................................................

\section{Table}

1. Field and aerial reconnaissance in response to the November 30,2018 , Anchorage earthquake. 


\title{
Ground Failure Triggered by Shaking during the November 30, 2018, Magnitude 7.1 Anchorage, Alaska, Earthquake
}

\author{
By Alex R.R. Grant, Randall W. Jibson, Robert C. Witter, Kate E. Allstadt, Eric M. Thompson, and Adrian M. Bender
}

\section{Introduction}

The magnitude $(M) 7.1$ Anchorage, Alaska, earthquake occurred at 8:29 a.m. local time on November 30, 2018, about 12 kilometers $(\mathrm{km})$ north of Anchorage. The focal depth of about $47 \mathrm{~km}$ and the normal focal mechanism indicate that the earthquake occurred in the subducting slab of the Pacific Plate. The U.S. Geological Survey (USGS) ShakeMap (Worden and Wald, 2016) of this event ${ }^{1}$ (fig. 1) shows severe (intensity VIII) shaking near the epicenter; this caused significant damage in the urban and infrastructure center of Alaska and was felt throughout the Anchorage and Matanuska-Susitna Valley areas. The USGS Prompt Assessment of Global Earthquakes for Response ${ }^{2}$ (PAGER; Wald and others, 2010) system gave an "orange" alert within an hour of the origin time, indicating estimated economic losses in the range of $\$ 100$ million to $\$ 1$ billion with few fatalities. No fatalities were reported following the 2018 Anchorage earthquake, but considerable damages to roads, railway alignments, and homes were observed throughout the epicentral region. The 2018 Anchorage earthquake was one of the most damaging earthquakes in the United States in the past decade.

USGS near-real-time ground-failure products provide immediate estimates of the severity and extent of potential landslides and liquefaction following a major earthquake (Allstadt and others, 2016, 2017). Near-real-time maps depict landslide and liquefaction potential based on statistical models (Zhu and others, 2017; Nowicki Jessee and others, 2018) and are based on USGS ShakeMap ground-motion estimates and susceptibility proxies; the maps do not incorporate post-event observations of actual earthquake-related ground failures. Within half an hour of the M7.1 Anchorage earthquake, USGS ground-failure maps ${ }^{3}$ predicted a limited area (10-100 square kilometers $\left[\mathrm{km}^{2}\right]$ ) of potential landslides with little or no population exposure ( $<100$ people) and a significant

${ }^{1}$ Available at https://earthquake.usgs.gov/earthquakes/eventpage/ us1000hyfh/shakemap/intensity.

${ }^{2}$ Available at https://earthquake.usgs.gov/earthquakes/eventpage/ us1000hyfh/pager.

${ }^{3}$ Available at https://earthquake.usgs.gov/earthquakes/eventpage/ us1000hyfh/ground-failure/summary. area $\left(100-1,000 \mathrm{~km}^{2}\right)$ of potential liquefaction with limited population exposure (1,000-10,000 people). These estimates increased after the magnitude was refined and strong groundmotion data was incorporated into ShakeMap: the landslide model increased to significant area $\left(>10 \mathrm{~km}^{2}\right)$ and the liquefaction alert remained the same (although the estimated area affected increased). Overall, the population exposure levels did not change substantially. Spatial extents of ground failures predicted by these rapidly generated hazard products (fig. 2) included landslides along the Chugach Mountains front east and northeast of Anchorage, the southwest Talkeetna Mountains, and along the Turnagain Arm of Cook Inlet. The models predicted widespread liquefaction along river valleys, tidal flats, and estuaries, mostly in remote areas, but with some elevated probabilities within Anchorage and the Matanuska River valley. To improve the accuracy of future USGS nearreal-time earthquake products, such as the landslide and liquefaction alerts and maps shown in figure 2, correlation of observed ground failure with predictions by real-time products is necessary.

This report documents our observations of ground failure caused by the earthquake. We conducted field work from December 1 to 10, 2018, during the 10 days immediately after the earthquake. A team of six USGS scientists and engineers verified the presence or absence of ground failures throughout the area by conducting three helicopter overflight missions and several days of ground inspections. We focused our efforts on specific areas identified by citizen reports as well as where near-real-time products (fig. 2) predicted ground failure. Because of the history of large damaging earthquakes affecting Anchorage, we were interested in determining if landslides from past earthquakes may have been reactivated. We assessed the response of large translational landslides that moved during the 1964 M9.2 Alaska earthquake (Hansen, 1965; Jibson and Michael, 2009) to shaking that occurred during the 2018 Anchorage earthquake.

Preliminary comparisons of digital terrain models developed from airborne light detection and ranging (lidar) data $^{4}$ acquired before and after the earthquake characterize the largest landslides observed in Anchorage and Eagle River.

\footnotetext{
${ }^{4}$ Available at https://elevation.alaska.gov.
} 
AEC ShakeMap : 7 miles NW of Elmendorf AFB

Nov 30, 2018 08:29:29 AM AKST M 7.1 N61.35 W149.96 Depth: 46.7km ID:20419010

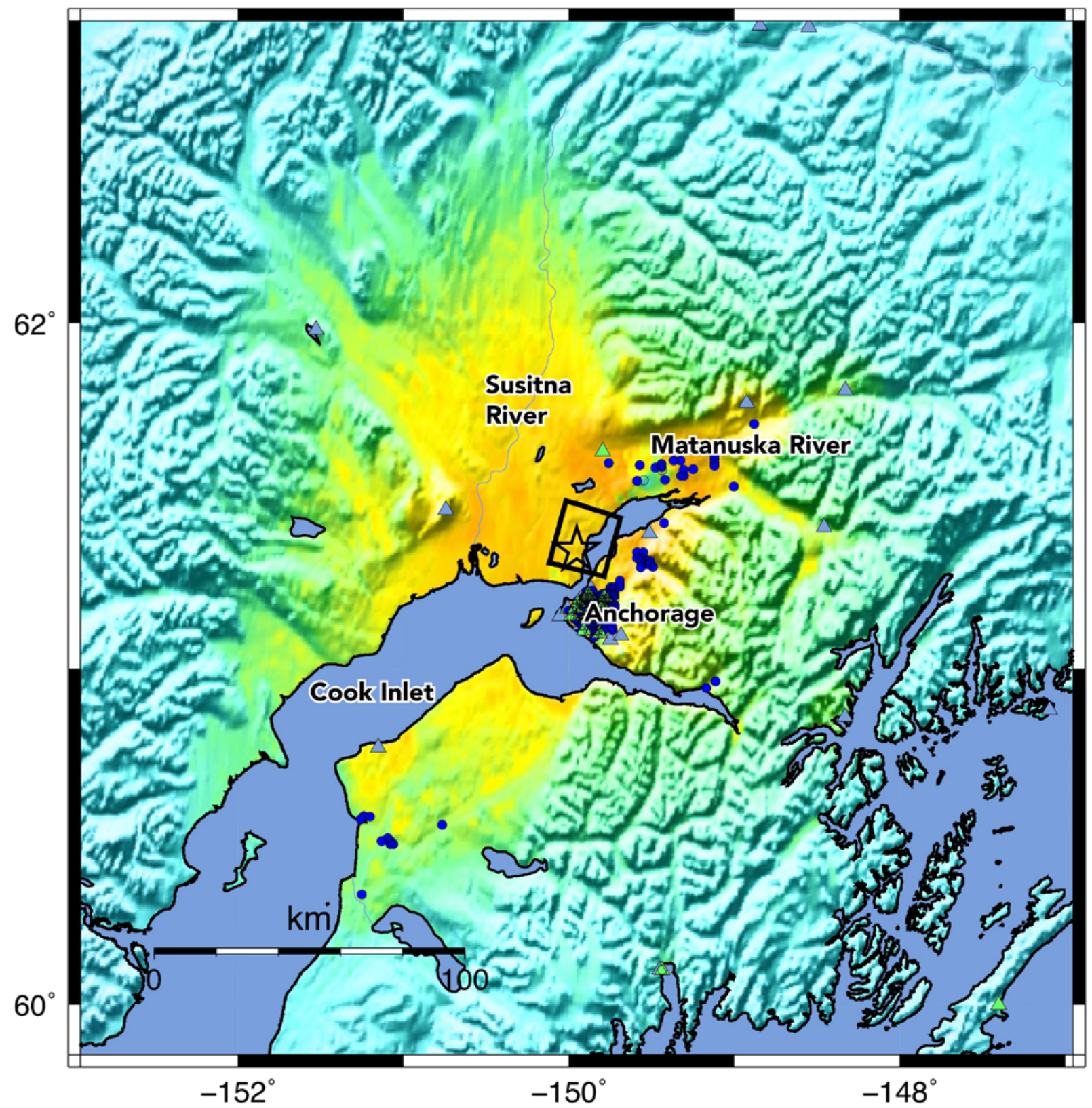

Map Version 8 Processed 2019-03-08 10:12:17 AM AKST

\begin{tabular}{|c|c|c|c|c|c|c|c|c|c|}
\hline $\begin{array}{c}\text { PERCEIVED } \\
\text { SHAKING }\end{array}$ & Not felt & Weak & Light & Moderate & Strong & Very strong & Severe & Violent & Extreme \\
\hline $\begin{array}{c}\text { POTENTIAL } \\
\text { DAMAGE }\end{array}$ & none & none & none & Very light & Light & Moderate & Mod./Heavy & Heavy & Very Heavy \\
\hline PEAK ACC.(\%g) & $<0.05$ & 0.3 & 2.8 & 6.2 & 12 & 22 & 40 & 75 & $>139$ \\
\hline PEAK VEL.(cm/s) & $<\mathbf{0 . 0 2}$ & $\mathbf{0 . 1}$ & $\mathbf{1 . 4}$ & $\mathbf{4 . 7}$ & $\mathbf{9 . 6}$ & $\mathbf{2 0}$ & $\mathbf{4 1}$ & $\mathbf{8 6}$ & $>\mathbf{1 7 8}$ \\
\hline $\begin{array}{c}\text { INSTRUMENTAL } \\
\text { INTENSITY }\end{array}$ & $\mathbf{I}$ & $\mathbf{I I - I I I ~}$ & $\mathbf{I V}$ & $\mathbf{V}$ & $\mathbf{V I}$ & $\mathbf{V I I}$ & VIII & IX & X+ \\
\hline
\end{tabular}

Scale based upon Worden et al. (2012)

Figure 1. ShakeMap produced by the U.S. Geological Survey Alaska Earthquake Center of the Cook Inlet region, Alaska, for the magnitude 7.1 earthquake on November 30, 2018. Star indicates the epicenter, box shows the outline of the rupture extent, colors depict the level of shaking. km, kilometer; peak acc., peak acceleration (in terms of the percentage of gravitational acceleration at the Earth's surface [\%g]); peak vel., peak velocity (in centimeters per second [cm/s]). 


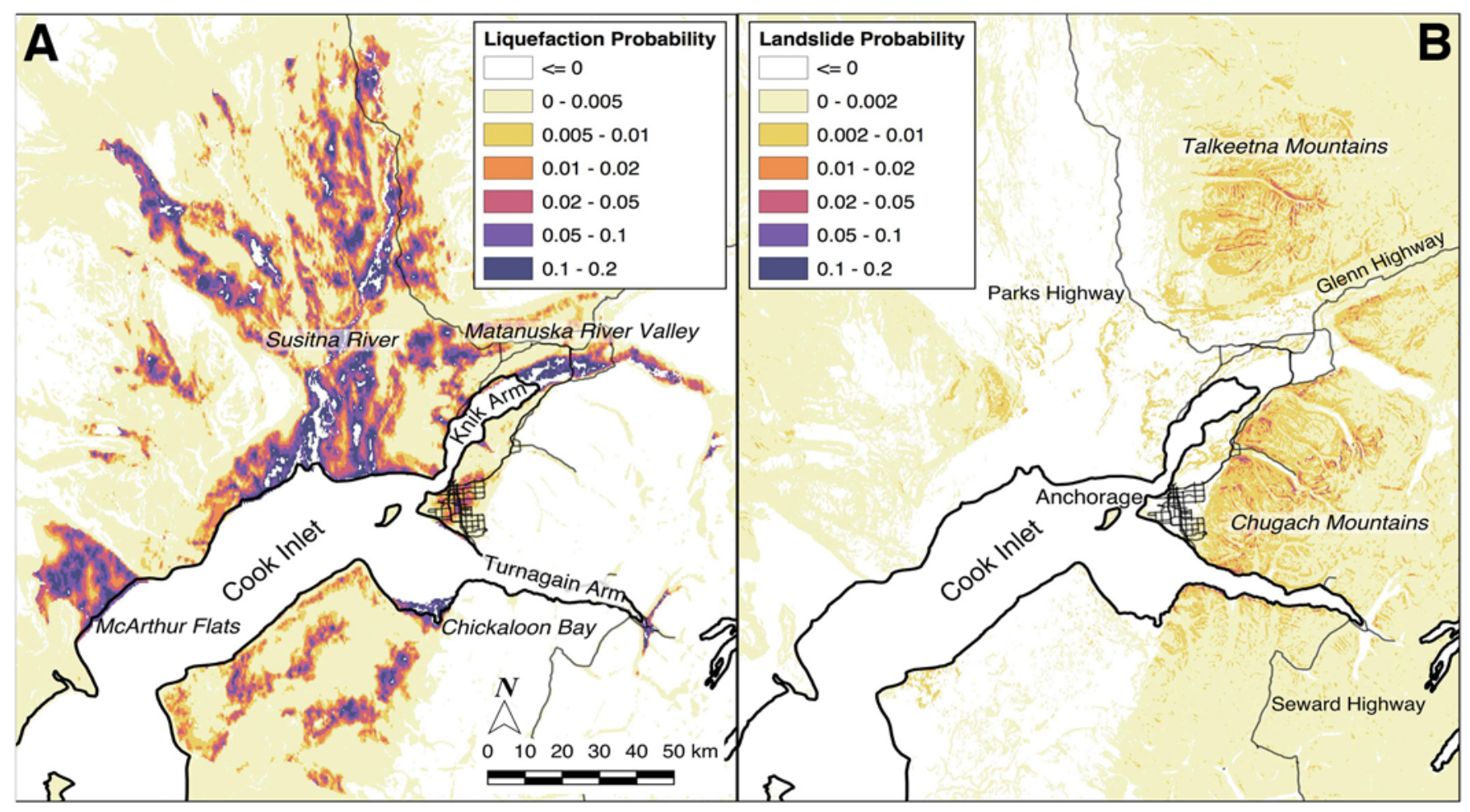

Figure 2. Maps of estimated ground failure probabilities in the Cook Inlet region, Alaska, following the magnitude 7.1 Anchorage earthquake. $A$, Liquefaction probabilities based on the Zhu and others (2017) model. $B$, Landslide probabilities based on the Nowicki Jessee and others (2018) model. km, kilometers.

\section{Methods}

Our goal was to document the presence or absence of ground failure (liquefaction and landslides) throughout the strongly shaken upper Cook Inlet region. Our investigation of ground failures extended south out of Anchorage to Portage and Ingram Creek, east along the Matanuska River, and north to the town of Willow along roadways and throughout the upper Cook Inlet area via helicopter (table 1; fig. 3). We were able to conduct one flight within 36 hours of the earthquake on December 1, 2018, to ensure rapid documentation of potential ground failure. We prioritized ground and overflight reconnaissance locations based on multiple criteria:

- Locations where USGS ground-failure models predicted significant hazard (fig. 2).

- Landslide locations from the 1964 Alaska earthquake and other areas known to be susceptible to ground failure in Anchorage (Hansen, 1965; Jibson and Michael, 2009).

- Areas susceptible to ground failure that lacked significant predicted hazard (including looking for the limits of ground failure).

- Areas where citizens reported ground-failure observations.

Ground-failure reconnaissance was conducted in teams of two to three scientists. During ground-based reconnaissance, we collected georeferenced images of liquefaction and (or) landslide features and mapped individual ground-failure features (using ArcCollector, a mobile geographic information system [GIS] application) as polygons of failure extent, mainscarp or tension-crack lines, or points with notes about the ground failure. We also noted observations of ground failure non-occurrence, as these are also especially important for calibrating ground-failure prediction models. Sites discussed in this report, and locations of field photographs in subsequent figures, are shown in figure 4.

Ground-failure features in this event were short lived for several reasons:

- The Alaska Department of Transportation and Public Facilities rapidly repaired road damage caused by landslides (fig. 5).

- Snow falling in the days immediately following the earthquake obscured slope failures, ground cracks, and sand boils. Snow in mountainous areas was significant enough to prevent observation of large features, such as the Rainbow Peak landslide (fig. 6A), captured shortly after the earthquake by local residents.

- Most sand boils were initially observed within tidal flats around the Cook Inlet where an $\sim 10$ meter (m) tidal range quickly removed sand ejecta or evidence of liquefaction.

In light of these issues, the timeline of making our observations was critically important. Confidence in our observations of the absence of ground failures diminishes as time from the earthquake increases, which can be highlighted 


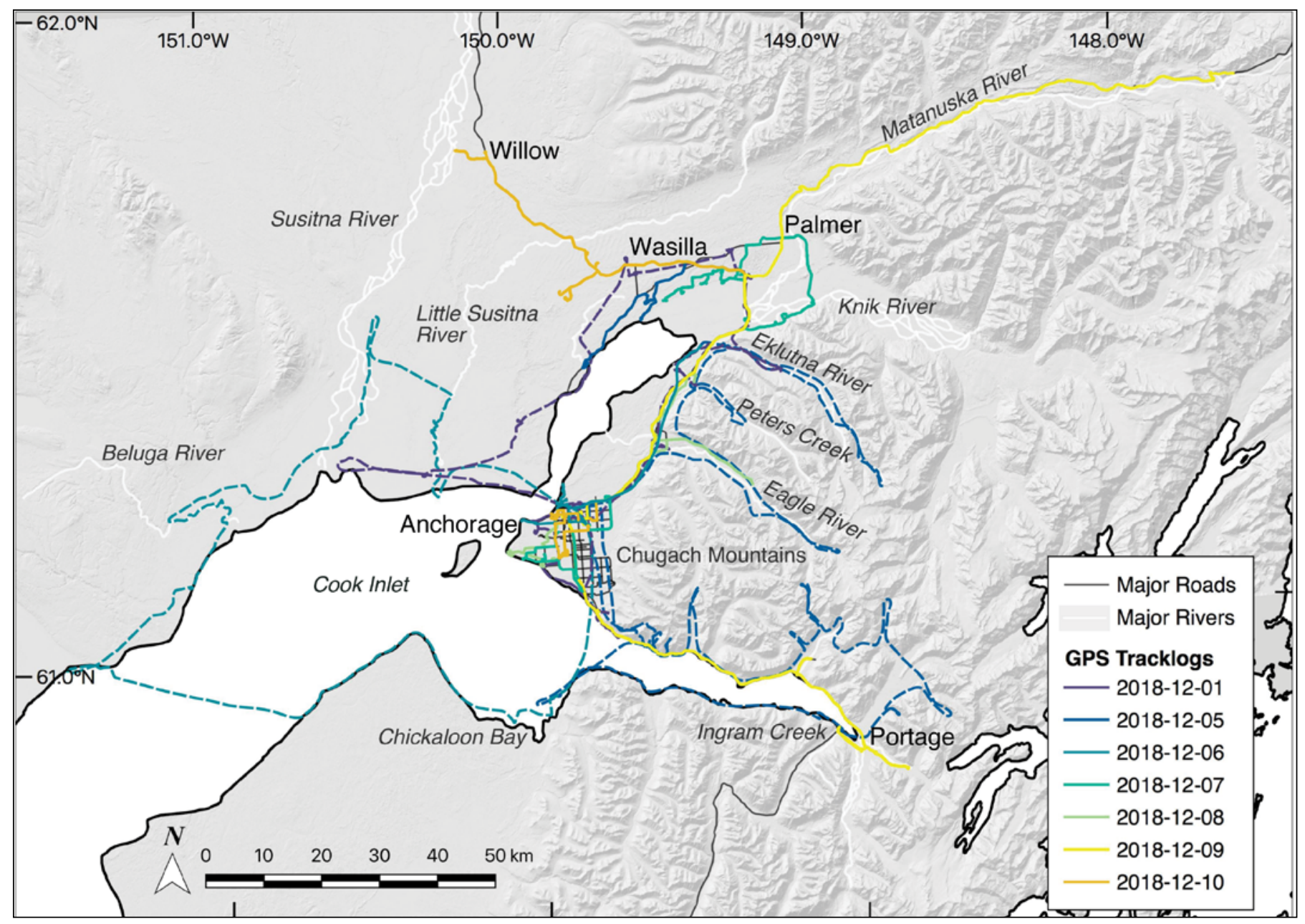

Figure 3. Map of Global Positioning System (GPS) tracks of field work in the Cook Inlet region, Alaska. Colors vary by date. Solid lines indicate ground-based fieldwork; dashed lines indicate aerial reconnaissance using a helicopter. GPS tracks were not collected on the December 4th reconnaissance within Anchorage.

Table 1. Field and aerial reconnaissance in response to the November 30, 2018, Anchorage earthquake.

$[\mathrm{km}$, kilometers]

\begin{tabular}{cll}
\hline \multicolumn{1}{c}{ Date } & Method' $^{\prime}$ & \multicolumn{1}{c}{ Objectives } \\
\hline $12 / 1 / 18$ & Aerial & Overflight reconnaissance of Municipality of Anchorage and Matanuska-Susitna Valley areas the day after the earthquake $(346 \mathrm{~km})$ \\
$12 / 4 / 18$ & Ground & Assess 1964 Turnagain Heights and Government Hill landslides \\
\hline $12 / 5 / 18$ & Aerial & Identify landslides in the Chugach Mountains $(563 \mathrm{~km})$ \\
$12 / 5 / 18$ & Ground & Map liquefaction features along Knik Arm \\
$12 / 6 / 18$ & Aerial & Identify liquefaction in the greater Cook Inlet region $(332 \mathrm{~km})$ \\
$12 / 6 / 18$ & Ground & Assess Turnagain Heights landslide, map ground failures in northern Anchorage \\
$12 / 7 / 18$ & Ground & Map liquefaction and landslide features in southern Anchorage \\
$12 / 7 / 18$ & Ground & Map liquefaction features along the Knik and Matanuska Rivers, assess levee damage near Palmer \\
$12 / 8 / 18$ & Ground & Map landslides near Peters Creek and Eagle River \\
$12 / 8 / 18$ & Ground & Map landslides and liquefaction in southern Anchorage \\
$12 / 9 / 18$ & Ground & Identify the limits of ground failure east along the Glenn Highway \\
$12 / 9 / 18$ & Ground & Map liquefaction features along Turnagain Arm \\
$12 / 10 / 18$ & Ground & Identify the limits of ground failure north along Parks Highway \\
$12 / 10 / 18$ & Ground & Map additional liquefaction features within Anchorage \\
\hline
\end{tabular}

${ }^{1}$ Aerial reconnaissance was conducted in a Robinson R-44 helicopter, distance flown given in parentheses; ground reconnaissance included sites accessible by road and investigated on foot. 


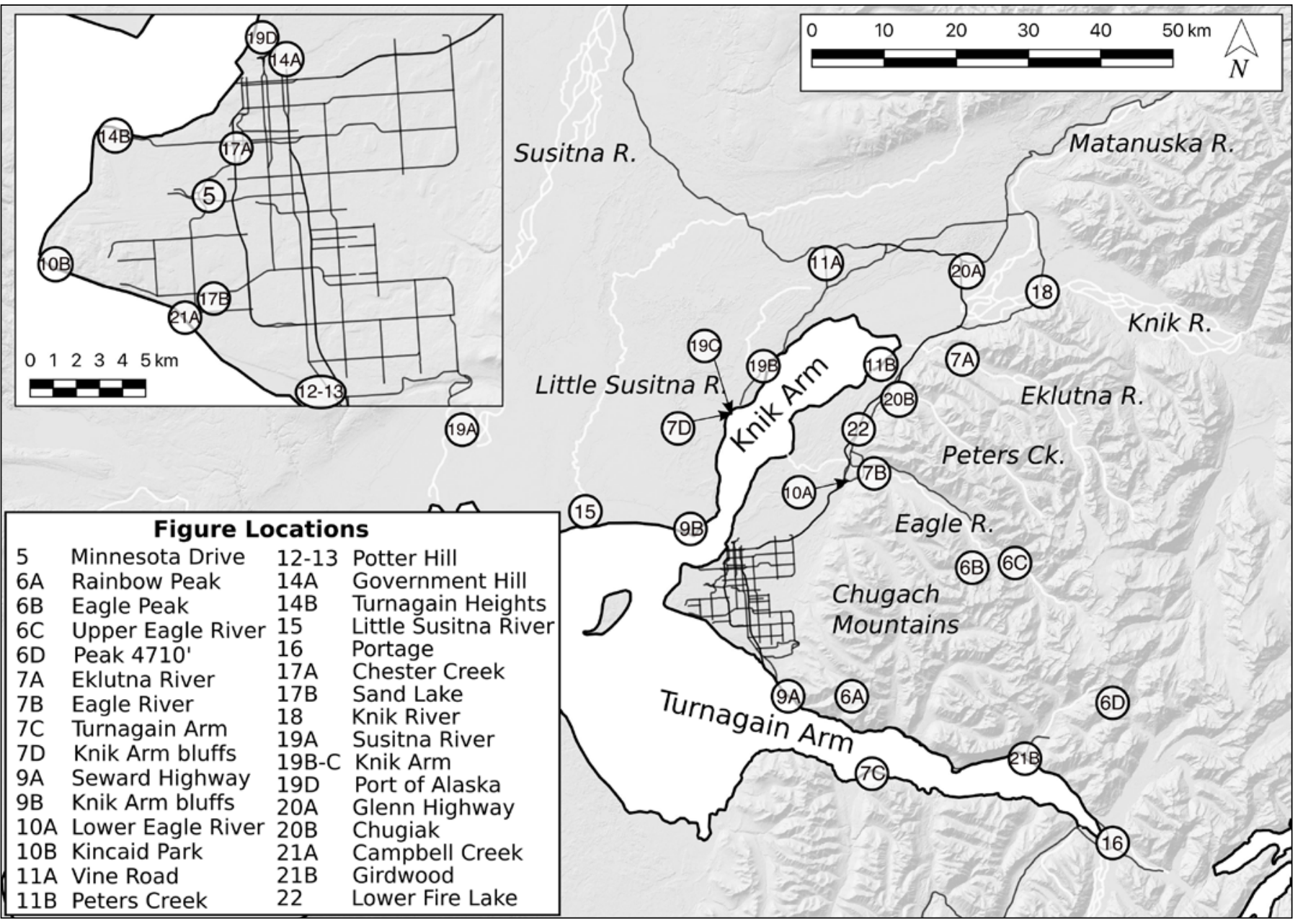

Figure 4. Overview map showing locations of named places and images (listed by figure number) discussed in the text.

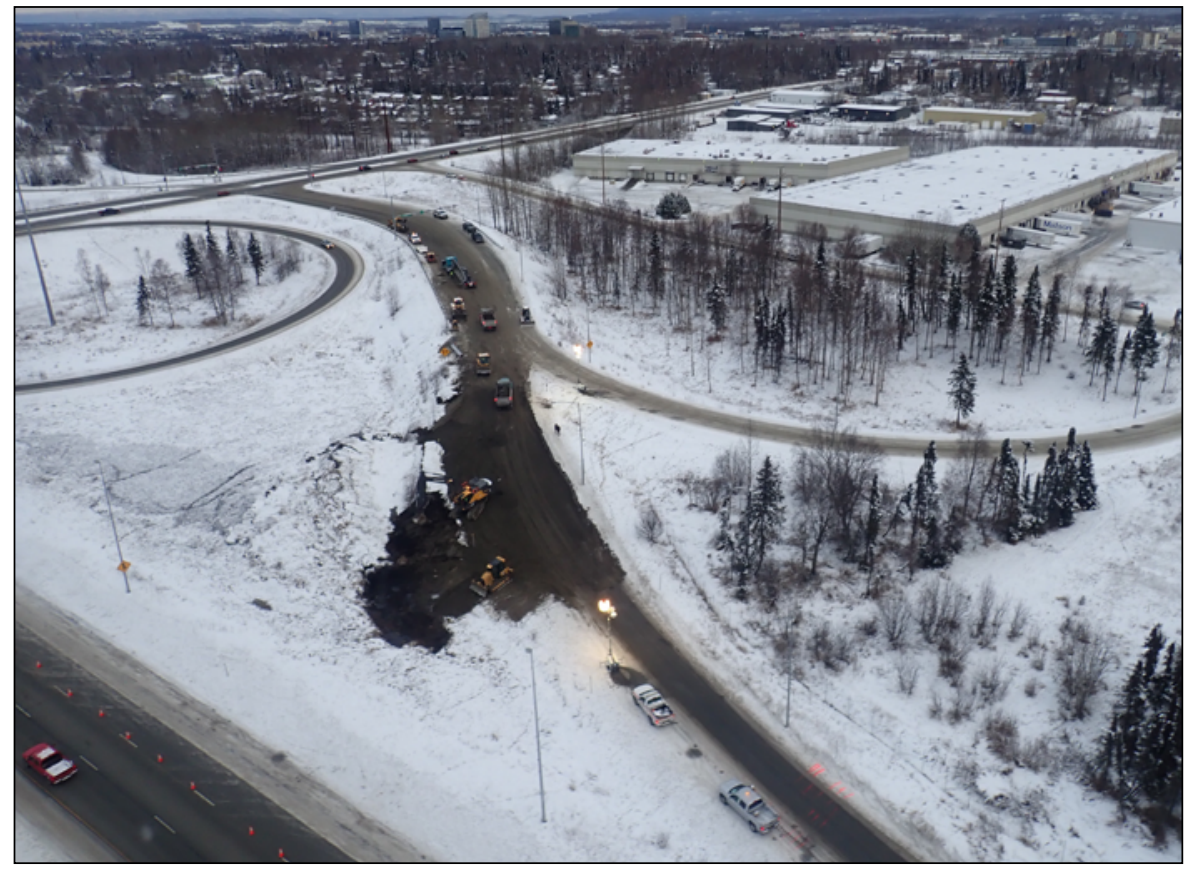

Figure 5. Photograph of ground failure of an engineered fill-slope embankment that damaged about 70 meters of the northbound offramp from Minnesota Drive to International Airport Road, in Anchorage, Alaska. On December 1, 2018, the day after the earthquake and time this photograph was taken, Alaska Department of Transportation crews had already begun repairs to the road. Location shown in figure 4. 
Figure 6. Photographs of rockslides, rock avalanches, and rockfalls. $A$, Rockslide on Rainbow Peak (photograph by Jeremiah Drage, resident). $B$, Rock avalanche below Eagle Peak (photograph by Colin Tyler, resident). C, Rockfall above Eagle River. $D$, Rockfall from Peak 4,710' (photograph by Heather Thamm, Chugach National Forest Avalanche Information Center). Locations shown in figure 4.

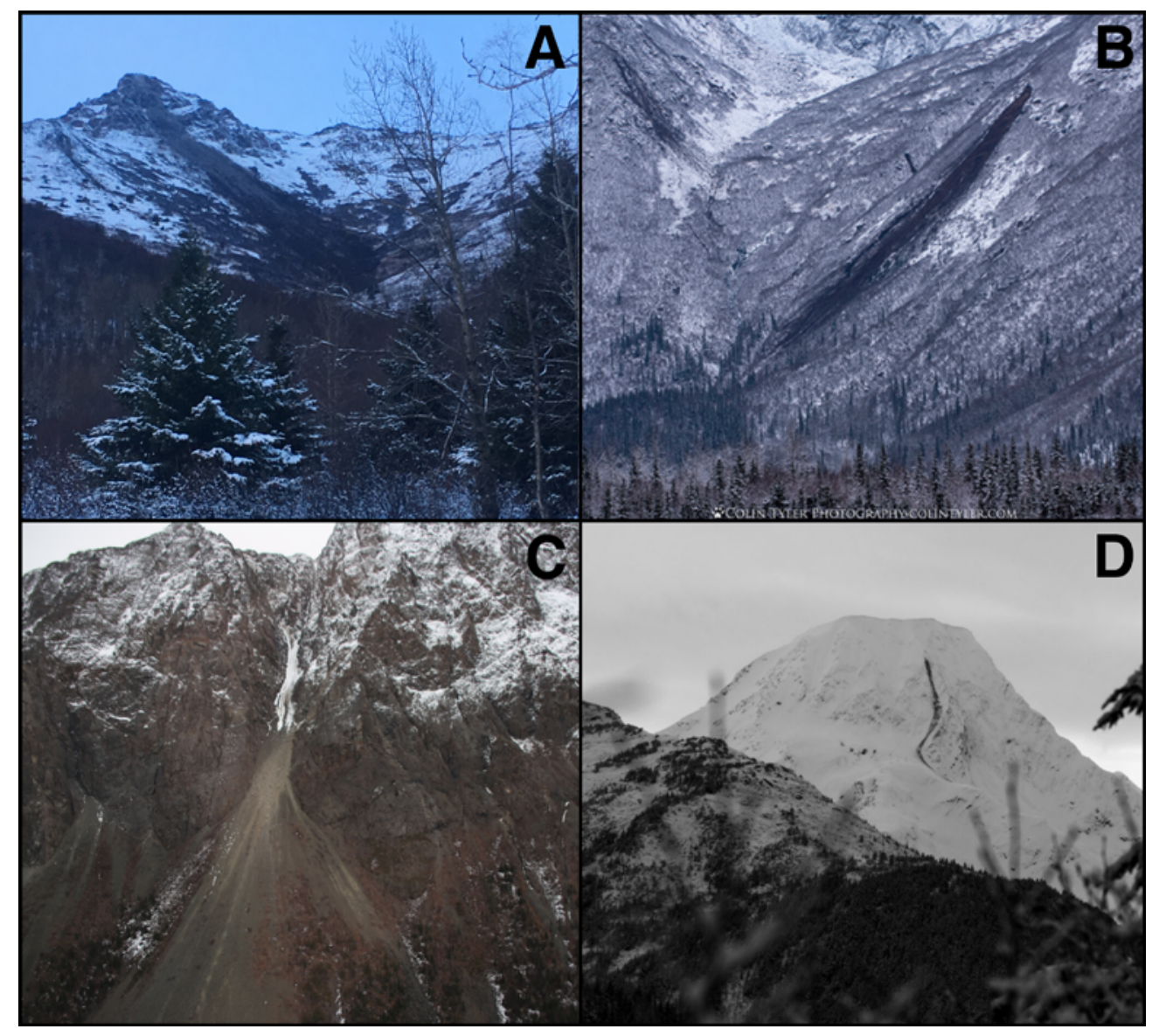

by two striking examples. First, the initial helicopter flight (December 1, 2018) documented extensive sand boils at the mouth of the Little Susitna River, but several tide cycles erased these features prior to a ground survey of this location on December 6, 2018. Second, citizen observations documented a large earthquake-triggered rockslide at Rainbow Peak (see fig. 6) above the Seward Highway, but snowfall obscured this feature prior to the second flight (December 5, 2018), when the rockslide was no longer visible.

\section{Observations}

We developed an initial inventory of 153 ground-failure features from the November 30, 2018, M7.1 Anchorage earthquake based on ground-based observations shortly after the earthquake (December 5-10) that includes the presence or absence of liquefaction, landslides, and individual crack traces of lateral spreads and incipient landslides. Field-mapped ground-failure observations and a set of 565 georeferenced and annotated images from both ground and overflight reconnaissance are available on ScienceBase (Grant and others, 2020).

\section{Landslides}

The landslide model (fig. 2) predicted localized zones of moderate to high landslide hazard within the western Chugach and southwest Talkeetna Mountains above Anchorage and the Matanuska Valley, respectively. The highest predicted landslide hazard was along the fairly densely populated lower reaches of Eagle River, Peters Creek, and steep slopes surrounding Anchorage (figs. 2 and 3). We discuss our landslide observations based in part on the landslide groupings of Keefer (1984), who used specific landslide nomenclature from Varnes (1978): disrupted landslides (falls and slides in rock and debris), coherent slides (block slides and slumps in rock and earth), and flow-type slides (debris and earth flows).

\section{Disrupted Landslides}

Rockfalls and disrupted soil- and rockslides typically are the most common types of landslides triggered by earthquakes (Keefer, 1984). Although these types of landslides were triggered by the 2018 Anchorage earthquake, they were neither numerous nor widespread. That observation must be qualified because fresh snow cover and limited light impeded our observations, but such a paucity of landslides for this type of earthquake has precedent. The 2001 Nisqually, Washington, earthquake, similar in many respects to the 2018 Anchorage earthquake (M6.8, normal focal mechanism, $50 \mathrm{~km}$ depth), also failed to trigger widespread landsliding (Highland, 2003).

The disrupted landslides we observed were shallow, involving only the uppermost few meters of rock and soil, and appeared to have moved rapidly because of their general occurrence on steep slopes. We observed disrupted landslides 
primarily along coastal bluffs, roadcuts along the Seward Highway, and the steep slopes within the Chugach Mountains. Nothing we saw suggested concentrated landslide activity in the Chugach Mountains; however, fresh snowfall completely obscured most high-elevation areas, especially in the southwestern Chugach Mountains, by the time of our overflight on December 5,2018 . We noted no signs of large valley-blocking landslides or freshly exposed source areas on steep slopes during our surveys. Such features likely would have been visible despite snow cover.

One of the largest known disrupted slides was photographed the day of the earthquake by a local resident: a rockslide off Rainbow Peak, visible from the Seward Highway (fig. 6A). This landslide was completely obscured by snow by the time of our overflight on December 5, 2018. The slide is visible under a thin coating of fresh snow in DigitalGlobe satellite imagery taken on December 3, 2018; examination of this image allows us to estimate a total length from the top of the source area to the distal end of the deposit of nearly $700 \mathrm{~m}$ and a total area of about 50,000 square meters $\left(\mathrm{m}^{2}\right)$. Landslide deposits reached the drainage, but the catchment is small, and deposits appear thin and coarse. We do not expect the deposits to impound a significant amount of water, but we cannot completely rule out this possibility without more data.

Several larger rockfalls and rockslides, photographed by a local resident on November 30, occurred along the steep valley walls of the Eagle and Eklutna Rivers. The largest was a rockslide with a debris trail several hundred meters long on the flank of a glacial valley leading up to Eagle Peak (fig. 6B); deposits were thin and trailed off before reaching the valley floor, which suggests a small source area. Though this rockslide was obscured by snow by the time of our overflight, we noted numerous signs of additional rockfalls and rockslides farther up Eagle River valley that likely were triggered by the earthquake (fig. $6 \mathrm{C}$ ). Most slope failures consisted of small detachments of rock onto existing talus slopes or long, thin, trailing deposits formed because of the steepness of these valleys. We saw no signs of major drainage blockages. Many of these slope failures started as falls and transitioned to flows as they reached shallower slopes, and most source areas were in bedrock. We noted a similar density and style of slope failures in the Eklutna River valley upstream from Eklutna Lake. Mountainous areas south of these two valleys showed no signs of similarly intense rockfall activity at the time of our December 5 overflight, but differences in snow cover could have biased our assessment. The Chugach National Forest Avalanche Information Center reported earthquake-triggered snow avalanches and rockfalls in mountainous terrain surrounding Girdwood (fig. 6D)

Other notable disrupted slides included raveling of new material from steep canyon walls cut into glacial drift by the Eklutna River downstream from the dam (fig. 7A) and failures in steep slopes along Eagle River between the Glenn Highway bridge and Eagle River Loop Road (fig. 7B). Preliminary comparisons of digital terrain models derived from lidar acquired before and after the earthquake show several shallow debris slides and avalanches in 40- to 50-m-high valley walls along Eagle River (fig. 8). These slope failures occurred in unstable colluvium, consisting of silt, sand, and gravel eroded from adjacent glacial drift that mantles

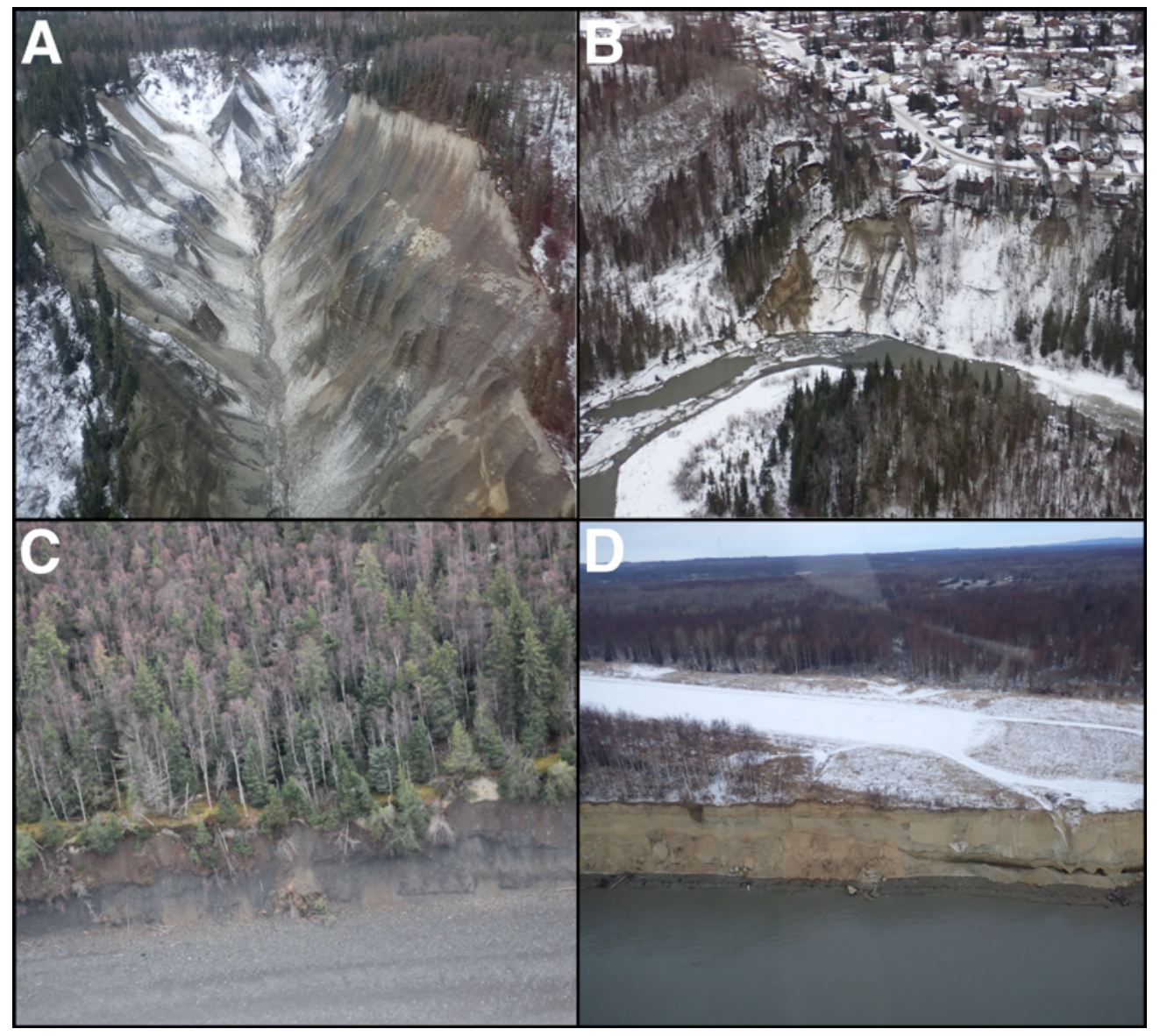

Figure 7. Photographs of disrupted landslides and coastal bluff collapses. $A$, Disrupted landslides in glacial drift along Eklutna River bluffs. $B$, Landslides in bluffs along the Eagle River west of Glenn Highway. C, Coastal bluff collapses along south side of Turnagain Arm. $D$, Coastal bluff collapses along west side of the Knik Arm. Locations shown in figure 4. 


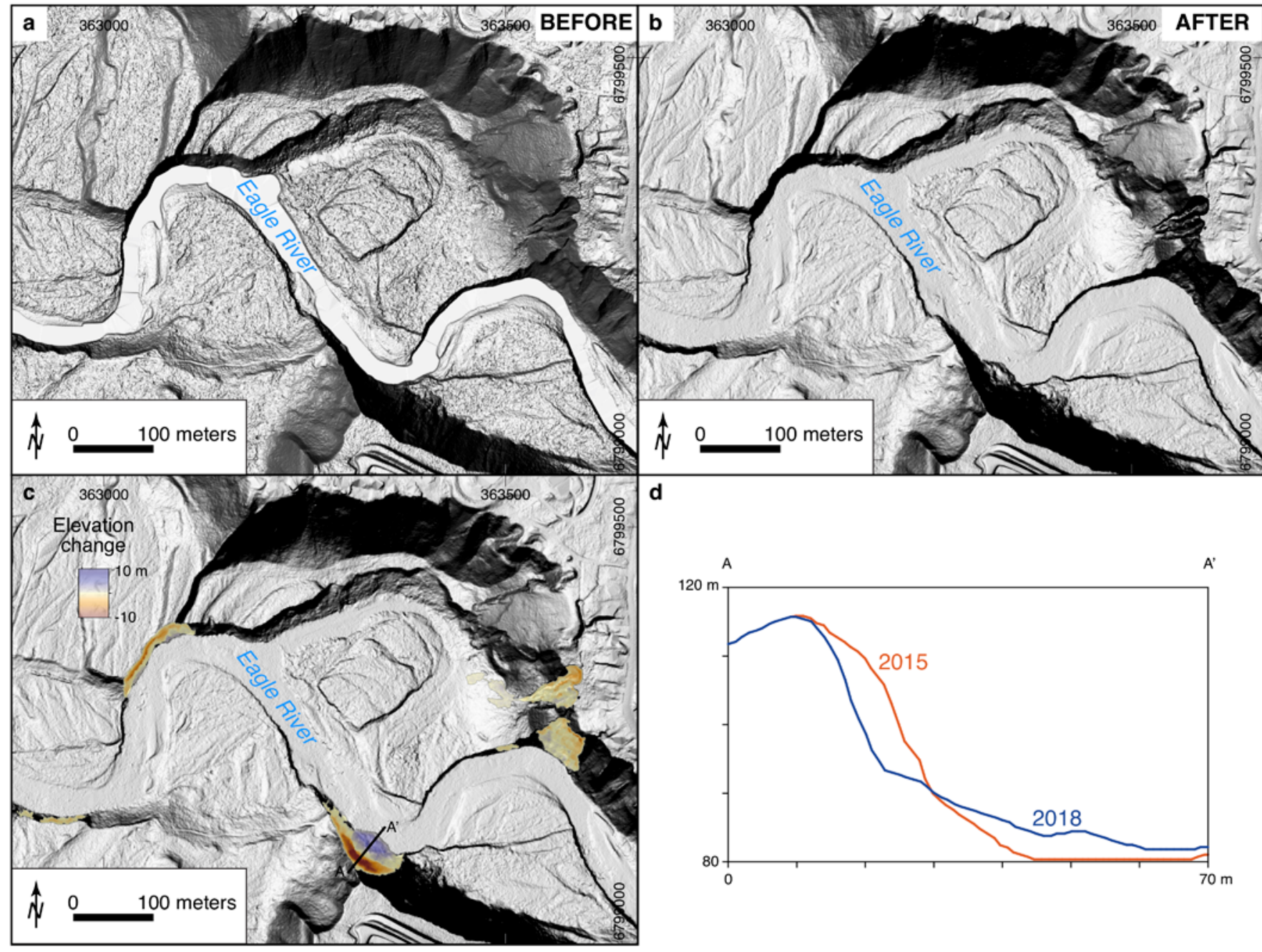

Figure 8. Digital terrain models (DTMs) derived from light detection and ranging (lidar) data acquired before and after the 2018 Anchorage earthquake used to estimate elevation changes induced by slope failure along the Eagle River (lidar available at https://elevation.alaska.gov). Maps use the North American Datum of 1983 (NAD83) Universal Transverse Mercator Zone 6 North coordinate system, in meters (m). a, Lidar DTM developed from data acquired for the Municipality of Anchorage in May 2015. $b$, Lidar DTM of the same area developed from data acquired in December 2018, after the earthquake. c, DTM showing elevation change between the 2015 and 2018 lidar data. Landslides occurred on steep slopes as much as $35 \mathrm{~m}$ high in the Eagle River canyon. Warm colors show negative elevation changes, greatest near landslide headscarps, and cool colors show positive elevation changes, where landslide deposits occur. The total range of elevation change varied from 4.6 to $-12.7 \mathrm{~m}$. $d$, Profile $A-A^{\prime}$ shows the elevation across a landslide before and after the earthquake. Location shown in $c$.

steep to very steep slopes (Schmoll and others, 1972; 1980). Schmoll and others (1980) specifically point out the susceptibility of the colluvium along Eagle River to slope failure, "Landslides and earthflows have been common in the past in these areas and may be reactivated, especially if the slope is disturbed."

During helicopter overflights we also observed collapsed coastal bluffs along the south side of the Turnagain Arm (fig. 7C) and the west side of the Knik Arm (fig. 7D). Few rapid, disrupted slides directly impacted infrastructure, except for several rockfalls along the Seward Highway (fig. 9A) that caused a temporary road closure (removed prior to our field reconnaissance) and failures along steep coastal bluffs (fig. 9B).

\section{Coherent Landslides}

Few deep $(>3 \mathrm{~m})$ coherent landslides were observed after the earthquake, although at least one led to significant impact to the built environment. Eight homes in the River Heights neighborhood of Eagle River were red tagged (unsafe for occupation) because of landslide movement in the steep slope behind the houses (fig. 10A). Our observations indicate that the slide plane may have been several meters deep. The basal slip surface appeared parallel to the slope in the upper part of the slide, but it extended below the houses at the base of the slope and appears to have curved upward at the toe, indicating possible 


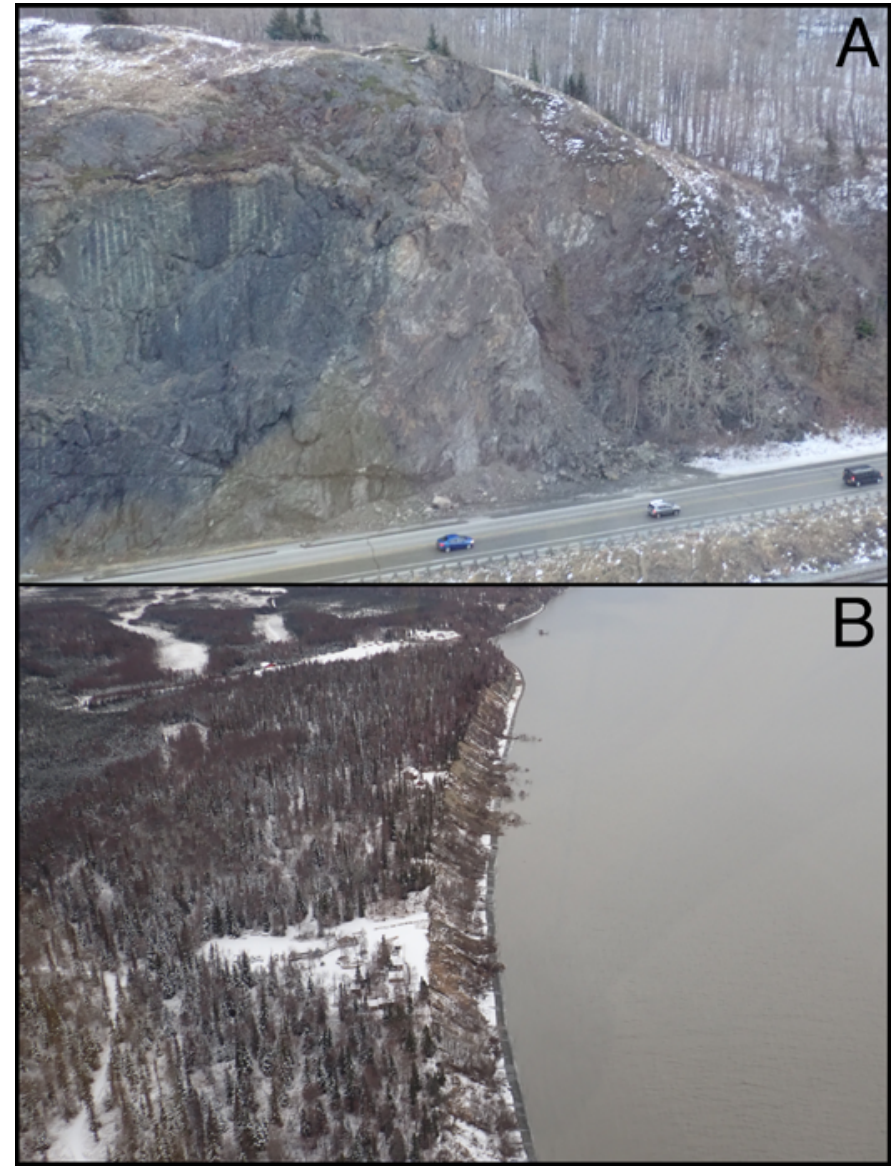

Figure 9. Photographs of rockfalls and coastal bluff landslides. $A$, Rockfall along Seward Highway. $B$, Coastal bluff landslides along Knik Arm west of Anchorage. Locations shown in figure 4.

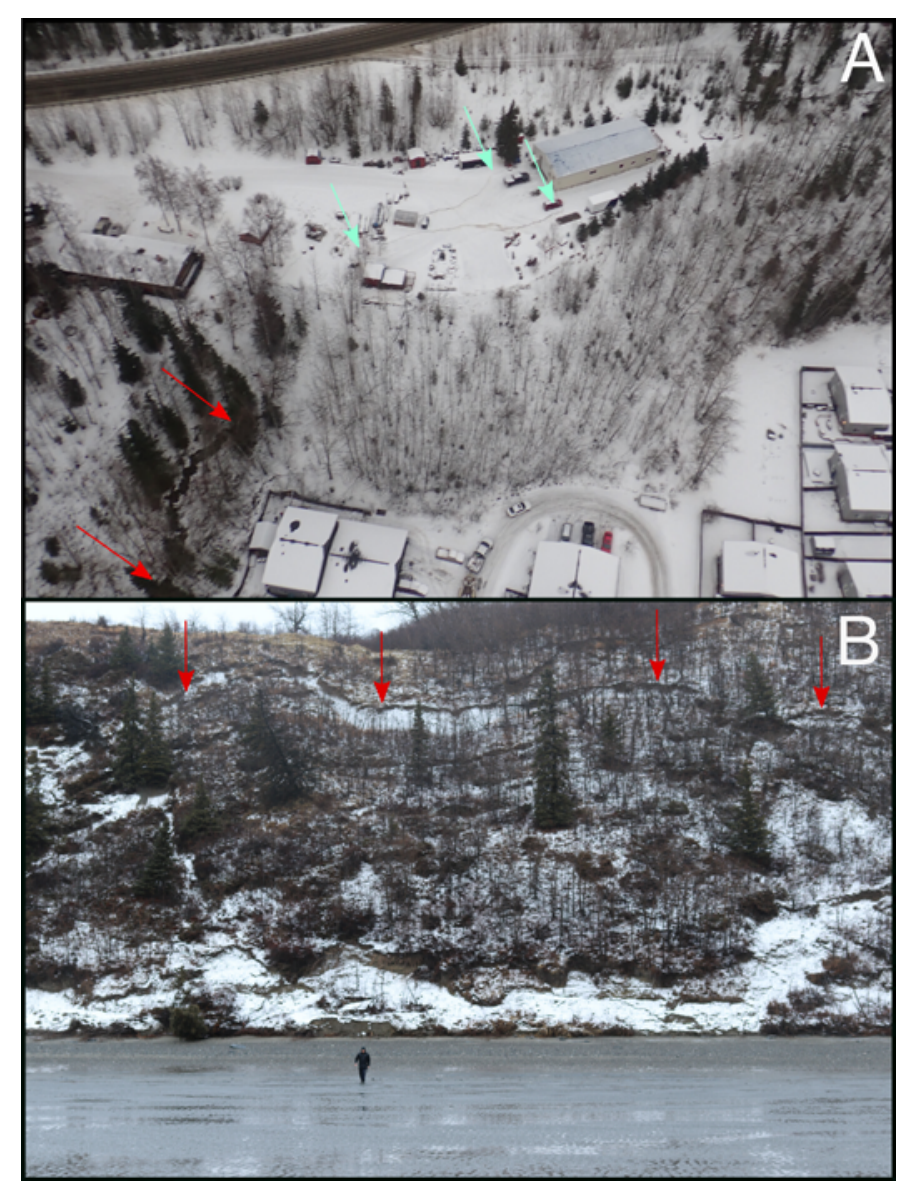

Figure 10. Photographs of coherent landslides. $A$, Coherent landslide that propagated into structures in the town of Eagle River; several structures below this slope were red tagged because of damage from deformation of this slope. Red arrows show the headscarp of the structure-impacting landslide, cyan arrows show additional extensional cracks above the slope. $B$, Landslide complex along the south-facing bluffs of Kincaid Park with many internal scarps. Primary scarp shown with red arrows. Locations shown in figure 4.

along the southwestern corner of Kincaid Park at the top of a $\sim 70$-m-high bluff (fig. 10B). Incipient cracks were also noted in several slopes near the Glenn Highway crossing of the Eagle River and along the tops of talus slopes along the lower Eklutna River.

\section{Flow Landslides}

The most damaging landslides triggered by this earthquake involved both natural and fill materials that developed complex, flow-like, landslide deposits. The most widely publicized were failures in engineered road fills at the north-bound Minnesota Drive offramp to International Airport Road in Anchorage (fig. 5) and along Vine Road south of Wasilla (fig. 11A). At Minnesota Drive, collapse of about $70 \mathrm{~m}$ of the offramp embankment appeared to occur from loss of bearing strength in underlying, in the southeastern corner of Kincaid Park, and a complex of cracks have as much as $1.5 \mathrm{~m}$ vertical and $1 \mathrm{~m}$ horizontal offsets 
poorly drained silt and fine sand of glacioestuarine origin (Combellick, 1999). The Alaska Department of Transportation had already begun repairs by the time of our first overflight on December 1. A similar engineered embankment constructed across a saturated bog also failed during earthquake shaking caused by loss of bearing strength in underlying deposits, which caused damage to about $90 \mathrm{~m}$ of Vine Road (fig. 11A). At Vine Road, saturated silt, fine sand, and (or) organic deposits fill a bog, which occupies a poorly drained area in glacial terrain confined by drumlins. Similar types of failures occurred in the railroad grade along the coastal bluffs $3 \mathrm{~km}$ north of the town of Chugiak. These failures appeared to initiate as slumps and then transitioned into a more flow-like behavior (fig. 11B). Several such slides occurred along a few kilometers of the railroad in this area and were being repaired at the time of our aerial overflights.

In the Potter Hill neighborhood of southern Anchorage, we observed several large flow slides (fig. 12). Near Potter Hill, a railroad grade has been cut approximately halfway up $\sim 35$-m-high coastal bluffs, creating a 15-20 m wide bench. The 1964 Alaska earthquake triggered destructive landsliding and ground cracking that extended about $3 \mathrm{~km}$ along this bluff (fig. 12B; Hansen, 1965; Hansen and others, 1966). The 1964 Potter Hill landslides

Figure 11. Photographs of roadway damage. $A$, Earthquake shaking caused loss of bearing strength in bog sediment that disrupted Vine Road in Wasilla, Alaska. B, Flow-slides along a railway alignment near Peters Creek. Locations shown in figure 4.

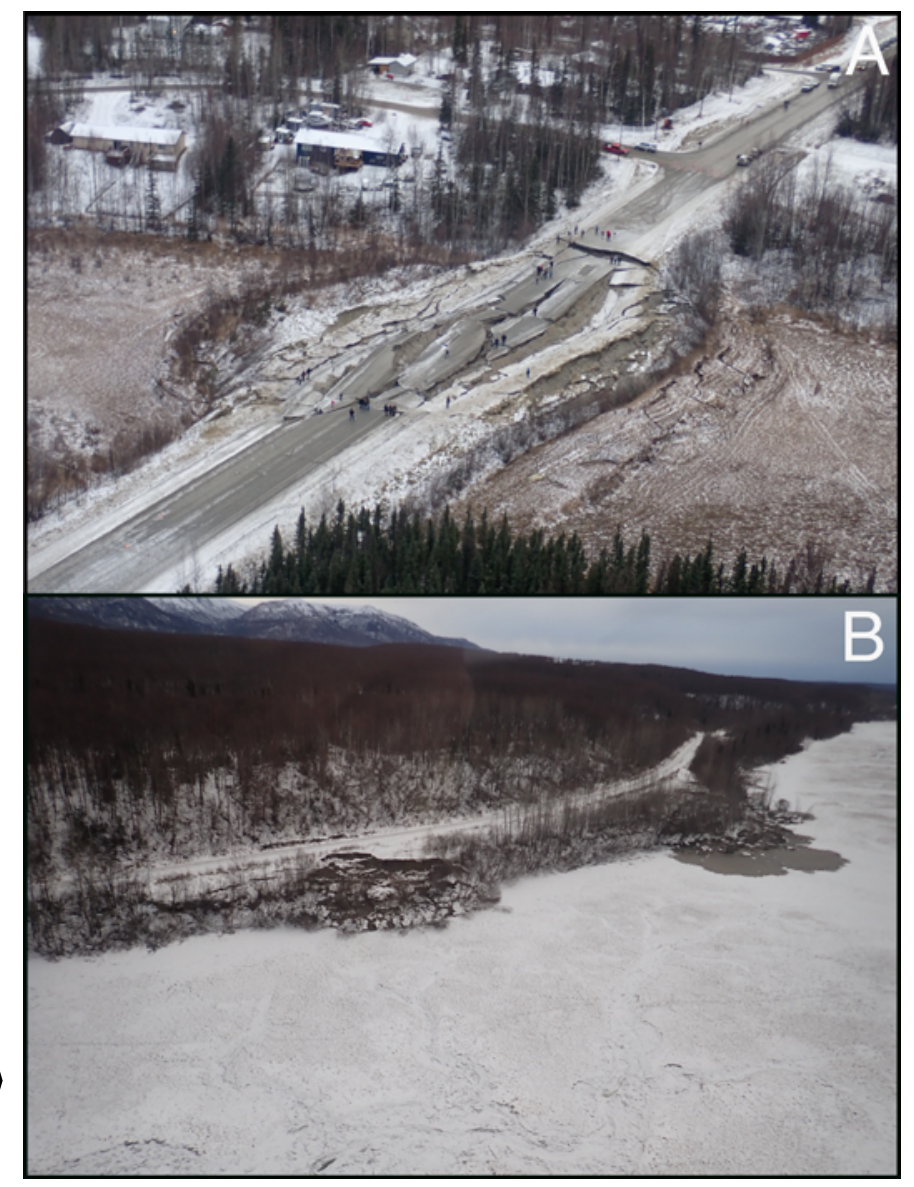

Figure 12. Photographs of the Potter Hill flow slides. $A$, Aerial photograph of two flow landslides near Potter Hill. $B$, Landslides triggered by the 1964 Alaska earthquake disrupting nearly a mile of the Alaska Railroad at Potter Hill (photograph by Reuben Kachadoorian of the U.S. Geological Survey, from Hansen and others, 1966). C, Main scarp of a slump/ flow slide at Potter Hill. Railroad grade is to the left, tidal flat to the right. Disrupted slide material and ponded drainage are ubiquitous. $D$, Tilted trees on landslide deposits at Potter Hill indicate multiple modes of movement: slumping, siding, and toppling. Location shown in figure 4.

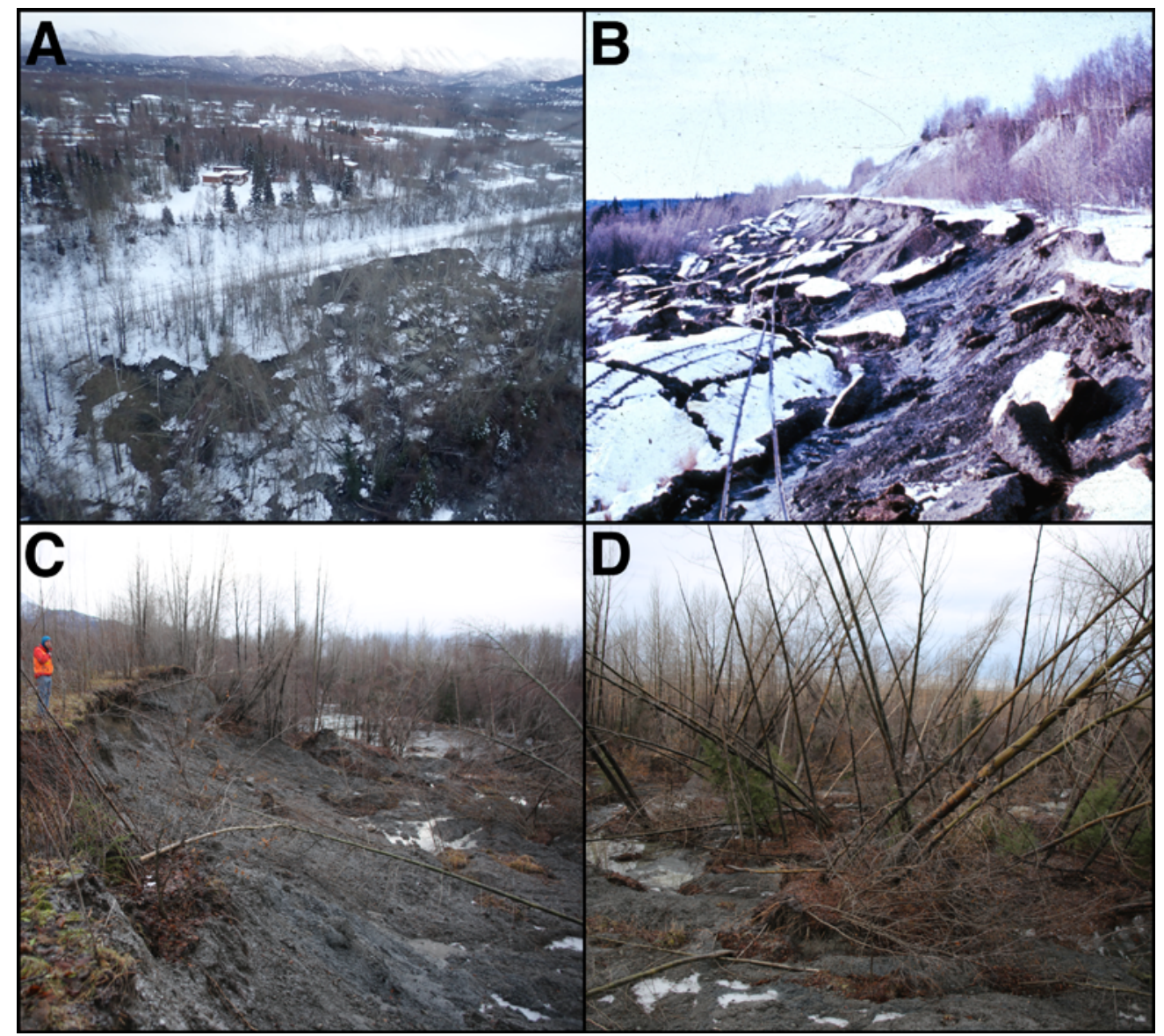


were described as having 5-10 m deep, steep slope-parallel slip surfaces and that they transitioned into flows after failure. Hansen (1965) documented several previous episodes of landsliding along this stretch of bluff from both previous earthquakes and heavy rainstorms. In 1964 and in some previous episodes of slope failure, segments of railroad track were damaged or destroyed. Hansen's (1965) description of the Potter Hill landslides indicates that they

“...consisted of elongate fragmented slump blocks rotated backward and broken into many pieces toward the base of the slope. In places at the toe, they turned into earth and mudflows derived partly from the intertidal silt of Turnagain Arm and partly, perhaps, from the clay-siltsand sequence in the lower part of the bluff."
This description perfectly matches our 2018 observations. The landslides we observed here extended along the same reach of bluff and had the same morphology as the Potter Hill landslides described in 1964 (figs. 12A, 12B, 13); they appear to have initiated as coherent slumps that then disaggregated and transitioned into flows (fig. 12C). Landslides occurred only on the lower part of the bluff below the railroad grade. Trees were askew and tilted in chaotic orientations (fig. 12D) indicating multiple movement geometries - slumping, sliding, and toppling. The 2018 landslides involved both failure of new bluff material and reactivation of some parts of the 1964 landslide deposits. The 2018 landslides were smaller, less extensive, and had shorter runout distances than those triggered in 1964. The railroad track was

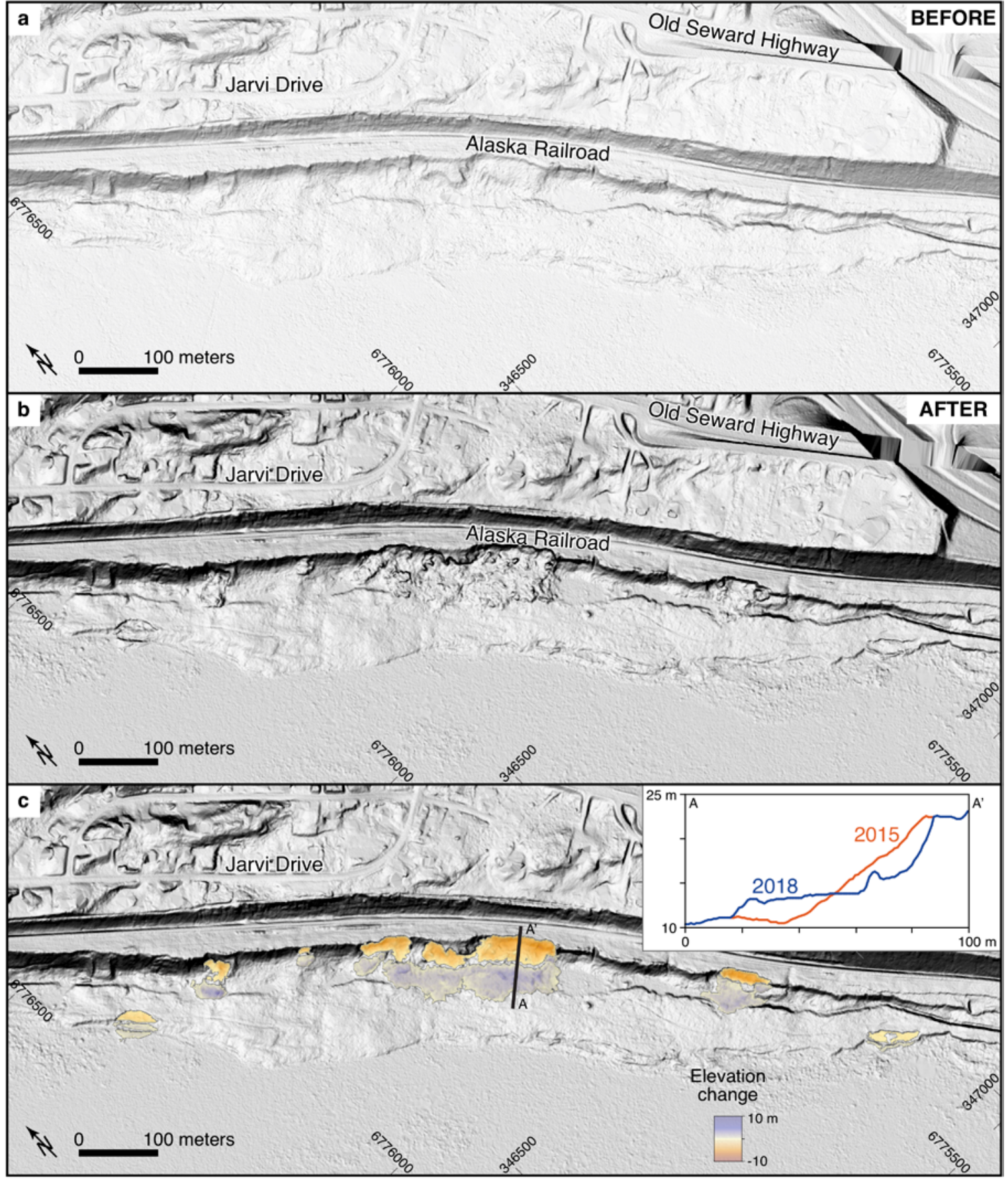

Figure 13. Digital terrain models (DTMs) derived from light detection and ranging (lidar) data acquired before and after the 2018 Anchorage earthquake used to estimate elevation changes caused by the Potter Hill landslides (lidar available at https://elevation. alaska.gov). Maps use the North American Datum of 1983 (NAD83) Universal Transverse Mercator Zone 6 North coordinate system, in meters (m). a, Lidar DTM developed from data acquired for the Municipality of Anchorage in May 2015. The Alaska Railroad runs along the road bed cut into the coastal bluff and showed no slumping in 2015 before the 2018 earthquake. $b$, Lidar DTM of the same area developed from data acquired in December 2018 after the earthquake. c, DTM showing the elevation change between the $\mathbf{2 0 1 5}$ and $\mathbf{2 0 1 8}$ lidar data. The Potter Hill landslides cut into the bench seaward of the railroad but did not damage the roadbed or tracks. Warm colors show negative elevation changes, greatest near landslide headscarps, and cool colors show positive elevation changes, where landslide deposits occur. The total range of elevation change varied from 3.7 to $6.0 \mathrm{~m}$. Profile $A-A^{\prime}$ shows the elevation across a landslide before and after the earthquake. 
not damaged in the 2018 earthquake largely because the railroad grade has been widened since 1964. However, future episodes of landsliding could pose a risk to the tracks with additional recession of the bluffs.

\section{Landslides from the 1964 Alaska Earthquake}

We visited several of the large, deep landslides triggered by the 1964 Alaska earthquake (M9.2) to determine if any of them showed evidence of reactivation during the 2018 earthquake. In summarizing observations from many studies of landslides from the 1964 earthquake, Jibson and Michael (2009) concluded that these large, deep landslides are triggered only by subduction-zone earthquakes that generate very long durations (several minutes) of strong shaking. Documenting the response of these landslides to the 2018 shaking provides an opportunity to test this argument and assess the hazard from reactivation of these landslides in other types of earthquakes that have shorter shaking durations.

The 1964 Government Hill landslide is located about $1 \mathrm{~km}$ north of downtown Anchorage on the bluff that forms the northern edge of Ship Creek channel (figs. 4 and 14A). The original landslide formed as large blocks along the bluff translated outward along a subhorizontal basal shear surface and a broad, deep graben formed between the main scarp and the largest of the landslide blocks (Hansen, 1965). During our field investigation, we discovered a new continuous crack that extends about $30 \mathrm{~m}$ along the crown of the main scarp of the 1964 landside at Sunset Park (fig. 14A). Additional discontinuous cracking no more than a few meters long was visible elsewhere along the old main scarp. Separation across the cracks was no more than 1-2 centimeters (cm), and we saw no downslope deformation, indicating no significant downslope movement.

We saw no evidence of remobilization of the Turnagain Heights landslide (fig. 4 and 14B). The Turnagain Heights landslide of 1964 devastated more than $0.5 \mathrm{~km}^{2}$ of a residential neighborhood and destroyed about 75 homes; the slide is located about $5 \mathrm{~km}$ southwest of downtown Anchorage along the bluffs on the south coast of Knik Arm in Cook Inlet. The original slide was a fairly deep $(\sim 60 \mathrm{~m})$ translational block slide that created a highly disrupted landscape of chaotic landslide blocks and intervening grabens of differing sizes (Hansen, 1965; Updike and others, 1988). We walked an axial transect through an unmodified part of the original landslide and observed fresh, laterally continuous, cracks bounding several grabens (fig. 14B). However, graben-bounding cracks generally had no more than about $1 \mathrm{~cm}$ of extension. We saw neither extensional cracking along the main scarp nor compressional deformation near the toe of the slide complex.

We also did not observe significant remobilization or displacement at other large, deep landslides from the 1964 earthquake in downtown Anchorage (Hansen, 1965) during our aerial reconnaissance. We were unable to field-verify this observation for every major 1964 landslide, and many of these areas have been significantly modified and urbanized since 1964, which might mask subtle deformation; thus, we cannot determine with certainty whether deformation occurred on these landslides. Absence of reporting or observations in our work and others (Franke and others, 2019) suggests remobilization of large 1964 landslides was not a significant phenomenon in the 2018 earthquake.

\section{Liquefaction}

Following large earthquakes, significant economic losses can result from liquefaction-induced settlement and lateral displacements because of the overlap of infrastructure with areas most susceptible to liquefaction, namely fluvially deposited sands and fill. Widespread evidence of liquefaction was observed after the 2018 Anchorage earthquake in natural fluvial-estuarine environments along the lower reaches of several rivers and streams draining into the Cook Inlet as well as in natural and fill deposits within Anchorage. Liquefaction likely played a role in damages to dozens of residential dwellings in southern Anchorage. Reconnaissance by others found decimeter-scale settlement and surficial cracks caused by liquefaction throughout the Jewel and Sand Lake regions of southern Anchorage resulting in settlement and tilting of nearby dwellings (see Franke and others, 2019, for details and locations of these features).

We documented three categories of liquefaction observations: (1) sand boils, (2) extensional cracks with sand ejecta, and (3) extensional cracks without sand ejecta, where liquefaction cannot be conclusively identified without additional subsurface investigations. Extensional cracks without sand ejecta were most commonly observed. Similarities in appearance between the extensional cracks in the presence of sand boils and extensional cracks without sand ejecta provides some evidence that these cracks likely resulted from liquefaction. We cannot rule out the possibility that some of these extensional cracks were caused by non-liquefaction-related slumping or sliding.

\section{Sand Boils}

The most notable evidence of liquefaction was seen at the mouths of the Little Susitna River (fig. 15) and Ingram Creek (fig. 16A). Linear patterns in the observed sand boils at the Little Susitna River suggest liquefaction of paleochannels or recent channels, similar to paleochannel liquefaction observed following the 2011 Tohoku, Japan (Pradel and others, 2014), and 2016 Kaikoura, New Zealand (Bastin and others, 2018), earthquakes. A second dense field of sand boils was observed within the tidal mudflats of Ingram Creek near Portage during our overflight on December 5. Sand boils below Ingram Creek were spaced more irregularly than those observed at the Little Susitna River. An example of the ephemeral nature of much of the evidence of ground failure following earthquakes, these sand boils were unrecognizable during our ground-based reconnaissance of the Ingram Creek mudflats just 4 days later. However, we documented soft irregular depressions that likely represent relict sand-boil vents (fig. 16B) remaining after tidal erosion of loose sand ejecta. Additional possible relict sand boils were observed near Portage and along the north shore of the Knik Arm (figs. 16C, D). Features 


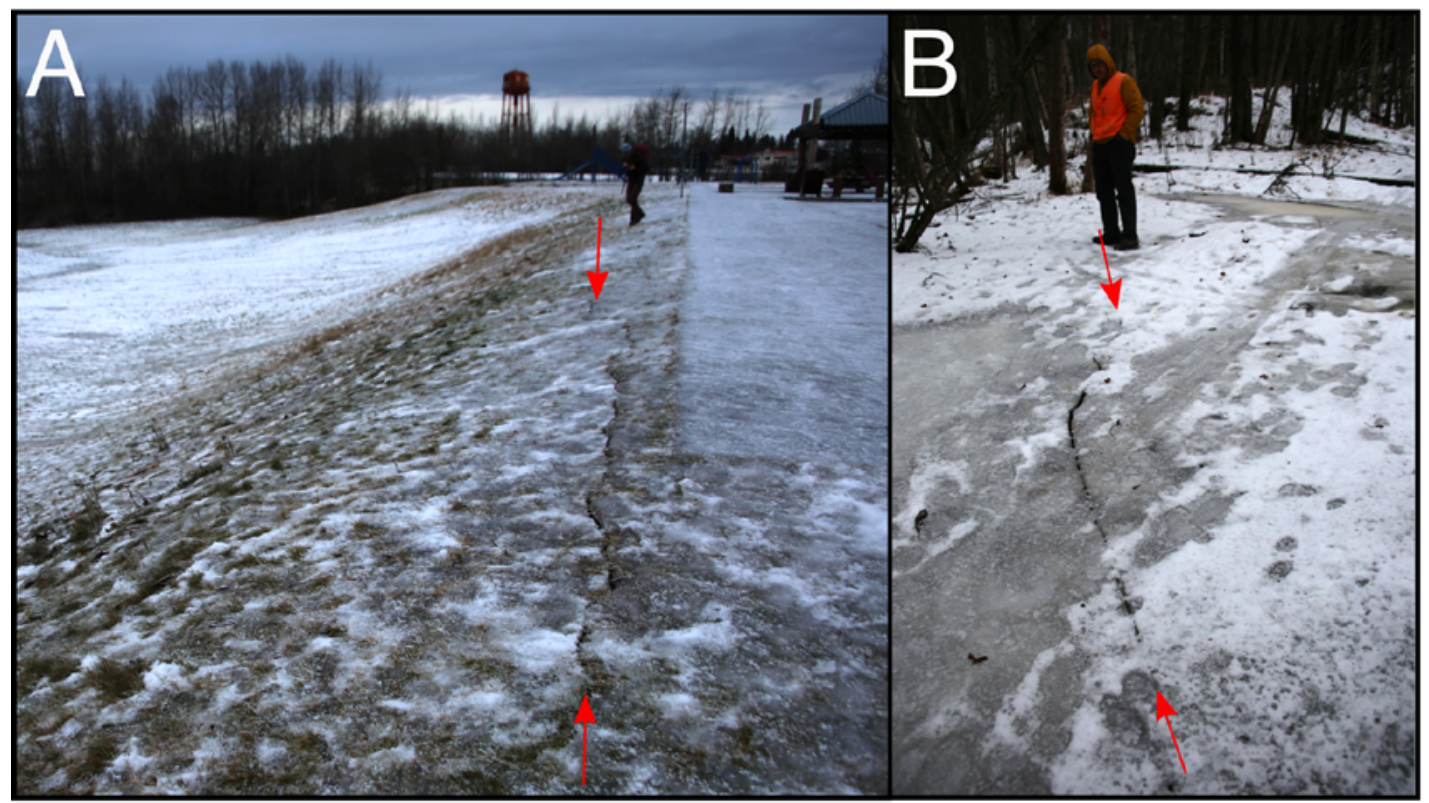

Figure 14. Photographs of minor cracking along 1964 landslide grabens in Anchorage. $A$, Fresh crack along the main scarp of 1964 Government Hill landslide at Sunset Park. The crack that extends upward from the bottom center of the photograph is continuous for about 30 meters along the old scarp; it has 1-2 centimeters (cm) of extensional separation. No net downslope movement of the 1964 landslide mass is apparent. The 1964 landslide moved from right to left in the photograph. $B$, Crack extending along the edge of a graben that formed in the 1964 Turnagain Heights landslide. The crack is visible extending upward from the bottom left part of the photograph. This and several similar graben-bounding cracks on this landslide had about $1 \mathrm{~cm}$ of extensional separation. No evidence of net downslope movement of the 1964 landslide mass is apparent. Locations shown in figure 4.

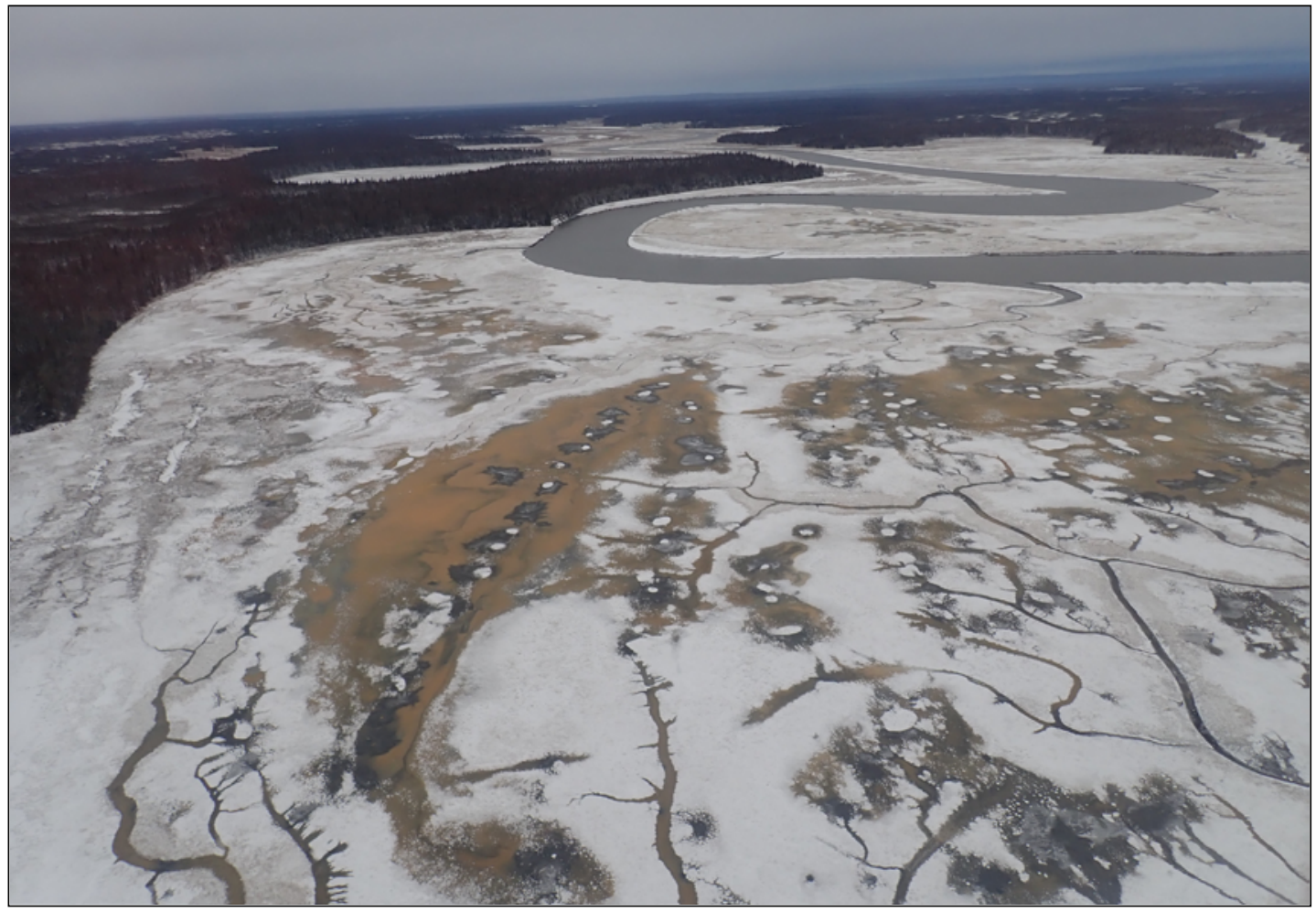

Figure 15. Photograph of a complex of sand boils along the mouth of the Little Susitna River north of Anchorage. Linear patterns of sand boils may be related to liquefaction of paleochannels. Location shown in figure 4. 
Figure 16. Photographs of sand boils and possible relict sand boils observed following the Anchorage earthquake. $A$, Welldefined sand boils near the outlet of Ingram Creek in Turnagain Arm on December 5, 2018. $B$, Possible relict sand boil vents at the mouth of Ingram Creek outlined by footprints. C, Possible relict sand boils near Portage. These steep-sided, water-filled voids in otherwise hard-packed riverbanks below high tide are believed to be the remnant vents from liquefaction during the earthquake. $D$, Close-up view of possible relict $\sim 60$-centimeterdiameter sand boil. Locations shown in figure 4.

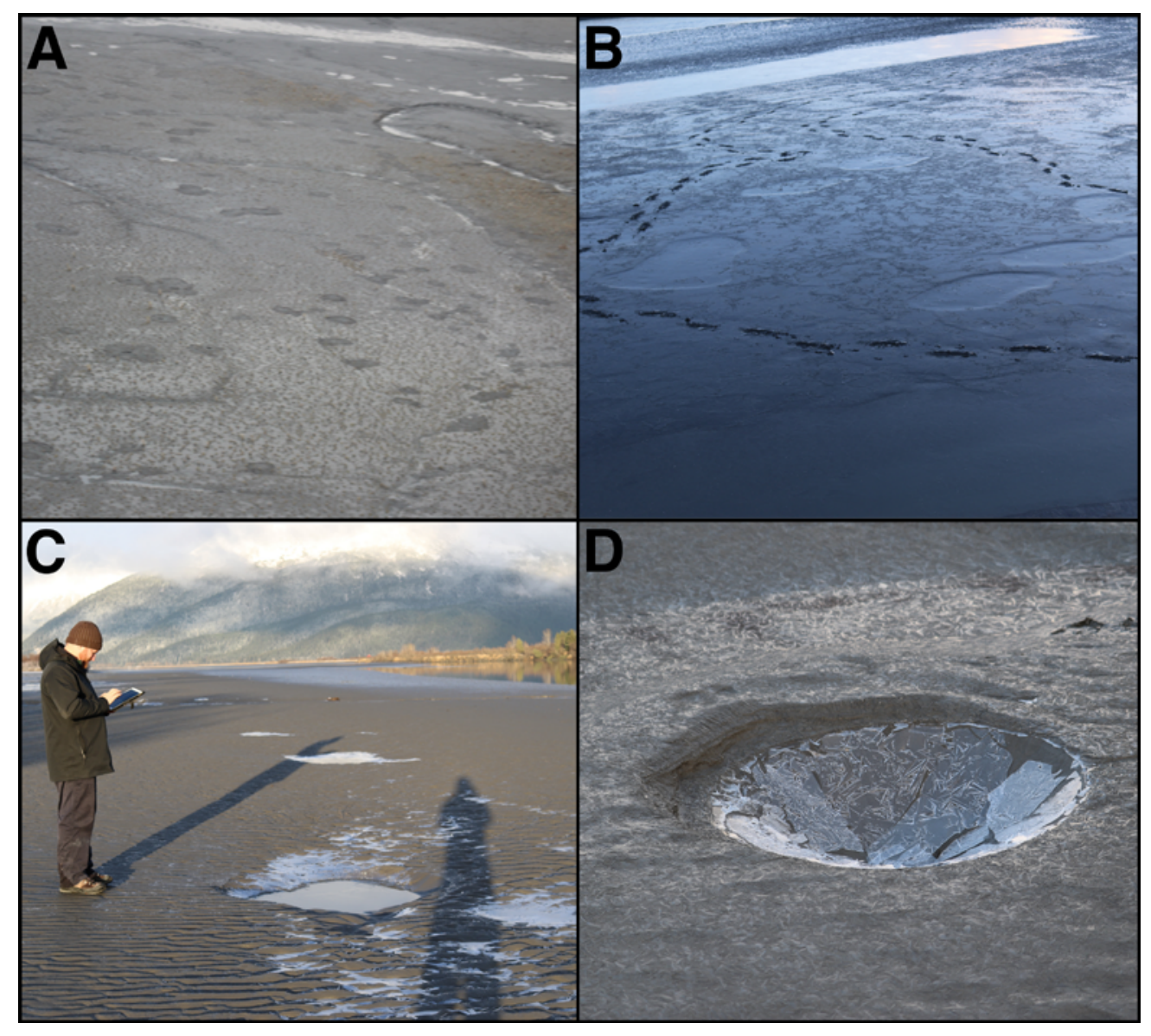

interpreted as relict sand boils were all steep-sided circular depressions. The depressions were filled with disturbed, loose soil surrounded by stiffer and partly frozen soil. All noted relict sand boils were below high tide level, near zones of lateral spreading or previous observations of sand boils where sand ejecta could have been eroded by tidal action.

Scattered reports of ejected sand in crawl spaces and foundations cracked by settlement and a bridge abutment in downtown Anchorage (fig. 17A) indicate liquefaction caused significant damage in some Anchorage locations and residential dwellings. In southern Anchorage near Sand Lake, a sand boil and small fissure were observed following the earthquake (fig. 17B).

\section{Extensional Cracks with Associated Sand Ejecta}

Extensional cracks with ejected sands where liquefactioninduced lateral spreading could be positively identified were observed near the north abutment of the Old Glenn Highway crossing of the Knik River (fig. 18). Extensional cracks within point-bar sands extended semicontinuously along a $\sim 175 \mathrm{~m}$ stretch of the Knik River just downriver from a nearby highway bridge. Interestingly, we observed no displacements or damage to the bridge or lateral spreading just upriver. Typical crack widths downriver from the bridge were $10 \mathrm{~cm}$, reaching a maximum of $\sim 50 \mathrm{~cm}$. Cracking was observed continuously through surficial sand and ice. Sand ejecta was observed frozen to the surface of a $\sim 15$-cm-thick sheet of ice (fig. 18). At the nearby Eklutna Tailrace, we observed additional extensional cracks (generally $7.5-10 \mathrm{~cm}$ wide but extending to $30 \mathrm{~cm}$ in places) with clean sand within the freshly exposed surfaces. Observations made by local residents prior to our arrival reported larger extensional (lateral spreading) cracks near the Eklutna Tailrace site within river gravels as wide as $\sim 75 \mathrm{~cm}$. However, these were obscured by snow during our reconnaissance.

\section{Extensional Cracks without Associated Sand Ejecta}

Most evidence of liquefaction from the 2018 Anchorage earthquake involved extensional cracking we associated with lateral spreading without clear evidence of sand ejecta. Notable examples include highly disrupted cracking and displacement on the banks of the Susitna River (fig. 19A) and along the shoreline of the Knik Arm (figs. 19B, C). Extensional cracks commonly were highly angular (for example, figs. 19A, $B$ ) and were preserved in a seasonally frozen crust of soils. Although we do not expect frozen surficial soils to have liquefied, we interpret their blocky and irregular displacements to reflect deeper subsurface deformation, likely caused by liquefaction of susceptible and unfrozen soils. Lateral spreading was also observed at the northern edge of the Port of Alaska (fig. 19D) as well as sand boils in the tidal flats at a nearby public boat launch. 


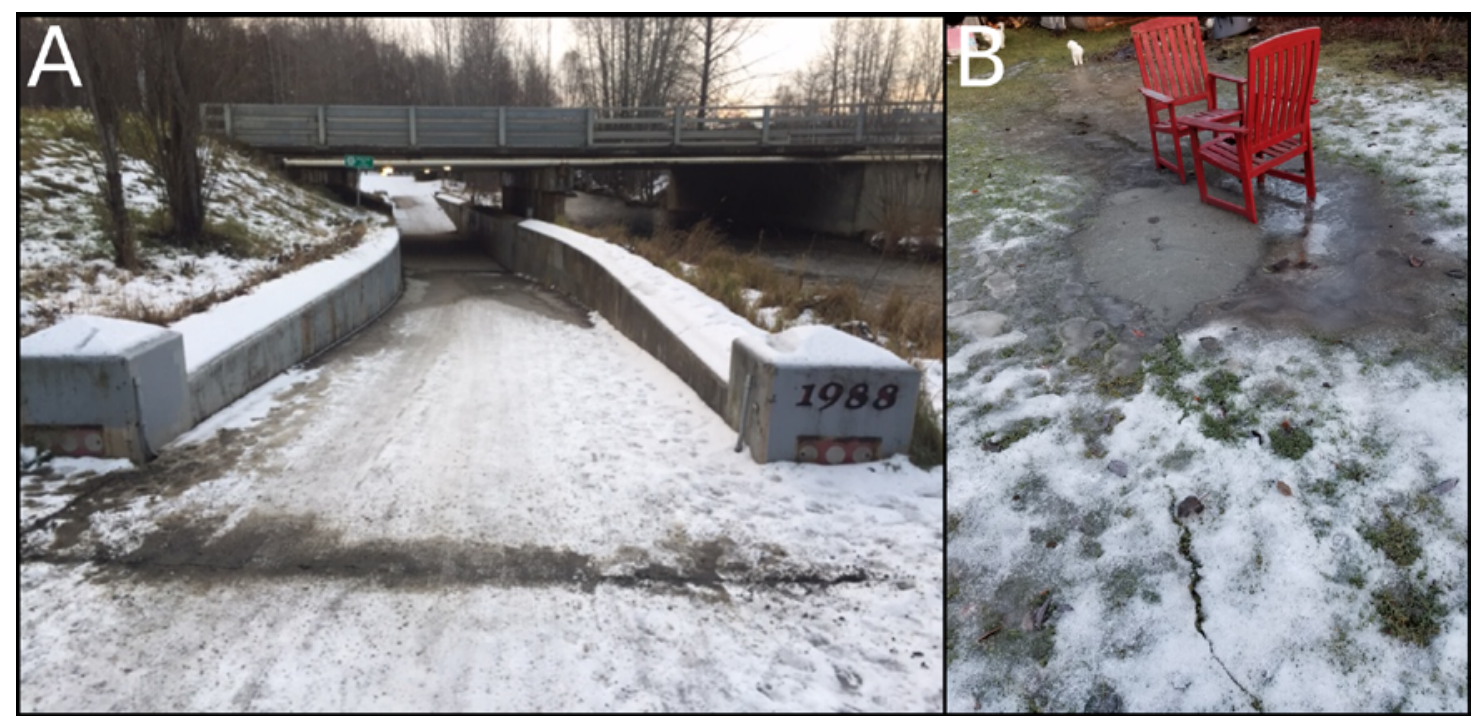

Figure 17. Photographs of evidence of liquefaction in Anchorage. $A$, Sand ejecta along the Chester Creek trail in Anchorage near the $C$ Street overpass (photograph by Janet Curran, U.S. Geological Survey). Minor tilting of the bridge abutment was observed at this site. $B$, Sand boil in backyard of a house in southern Anchorage near Sand Lake. Sand boil is situated along a small fissure that propagated tens of meters through a house (located toward the top of the photograph). Settlement of part of the structure occurred close to the fissure (photograph by Roger $D$. Jones, resident). Locations shown in figure 4.

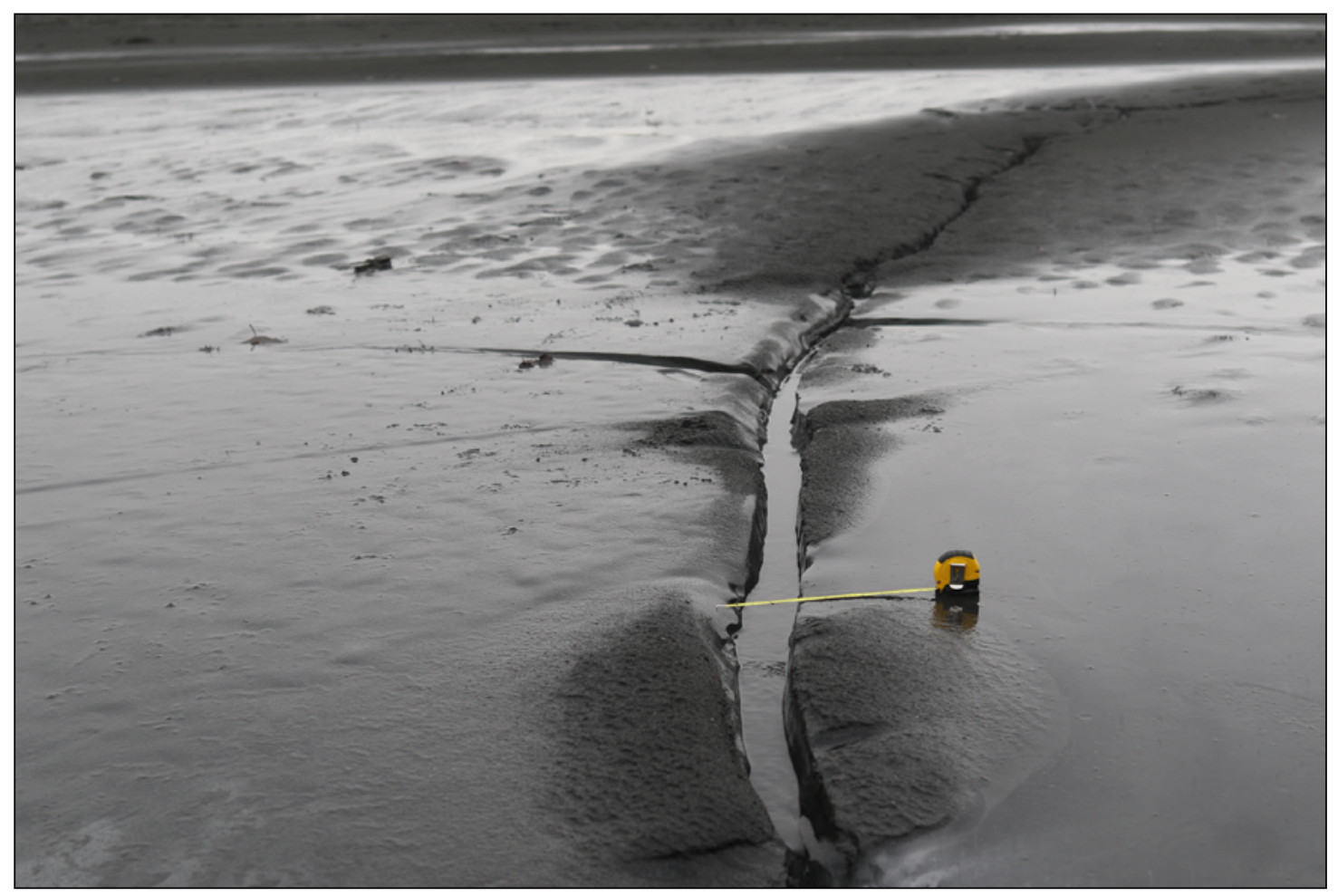

Figure 18. Photograph of extensional lateral-spread cracks on the north bank of the Knik River near the Old Glenn Highway. Sand ejecta are frozen on top of $\sim 15$ centimeters $(\mathrm{cm})$ of clear ice that rests on clean river sands. Tape extended $30.5 \mathrm{~cm}$. Location shown in figure 4. 
Figure 19. Photographs of extensional lateral-spread cracks without obvious sand ejecta. $A$, Angular extensional cracks within a point bar island along the lower Susitna River with an associated set of compressional ice cracks caused by lateral displacement. $B$, Disrupted extensional cracks caused by liquefaction. Individual cracks are as wide as 60 centimeters $(\mathrm{cm})$. Cumulative lateral displacement at this site was $\sim 1.5$ meters. $C$, Arcuate extensional cracks above mean high tide in Knik Arm. Individual cracks are $2.5-15 \mathrm{~cm}$ wide extended semicontinuously for several hundred meters parallel to the shore. $D$, Extensional lateral-spread cracks at the Port of Alaska.

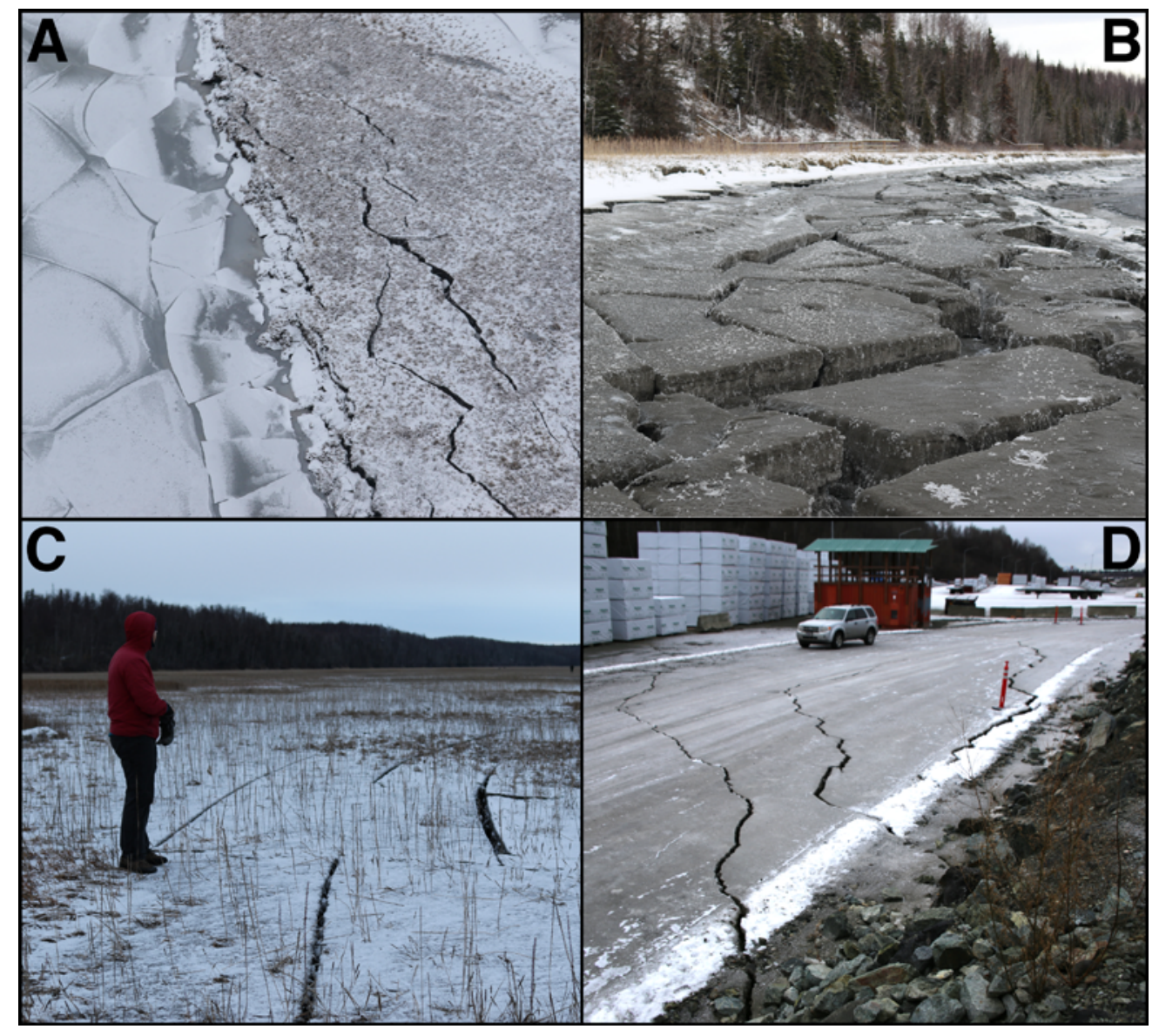

\section{Other Observations}

The most abundant and impactful style of ground failure triggered by this earthquake was extensional cracking not clearly associated with either landsliding or liquefaction. Many instances occurred adjacent to roads and residential structures near the edges of steep natural and fill slopes (fig. 20). In some instances, cracks propagated through existing buildings, or fill material moved downslope away from an existing structure on grade. This behavior was most common near the edges of graded building pads bounded by steep slopes. We noted widespread extensional cracking in the hilly residential areas of Peters Creek, Eagle River, and Chugiak (for example, fig. 20B). We did not make a comprehensive assessment, so other areas also may have been affected. Total horizontal and vertical offsets were typically tens of centimeters or less. The vast majority of cases we observed appeared to involve artificial fill and could be due simply to minor downslope slumping or settling, but we also observed cracking patterns in some locations that indicated potential incipient landsliding in both natural and fill slopes. Seismically generated cracking along the edges of slopes has been documented for other earthquakes (for example, Keefer and Manson, 1998; Jibson and others, 2018).

We also documented several river-bank collapses with vertical displacements as much as about $2 \mathrm{~m}$. Bank collapse was typically observed along small creeks and streams at or near

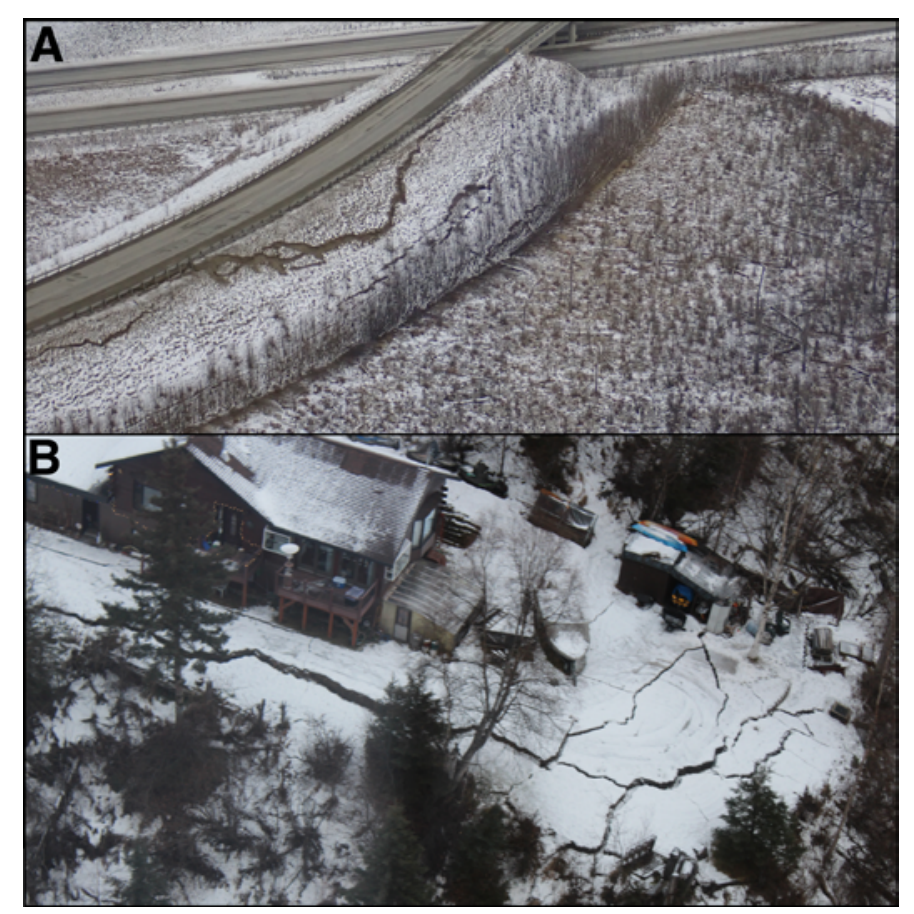

Figure 20. Photographs of extensional cracking. $A$, Extensional cracking in overpass embankment along the Glenn Highway. $B$, Extensional cracking and settling around a private residence in Chugiak. Locations shown in figure 4. 
mean high tide. Notable examples of this failure mode were along Campbell Creek (fig. 21A) within Anchorage and along Turnagain Arm below Girdwood (fig. 21B) in the remains of a forest that died because of tectonic subsidence in the 1964 Alaska earthquake. Marsh grasses covered in freshly deposited, unfrozen mud below the high tide line were the most common evidence of recent bank collapse. The bank collapses also were generally associated with recent extensional cracks. We did not observe ejecta of liquefiable materials at any bank-collapse sites. We suggest these bank collapses could either be lateral spreads caused by liquefaction that did not vent to the surface or simply slumping and (or) settlement of nonliquefiable material.

One unusual site of extensional cracking was the island in the center of Lower Fire Lake (fig. 22). The island appears to be composed of glacial till. Its south end was crisscrossed by extensional cracks that propagated across its summit in an " $X$ " pattern and then into the water. Blocks of ice adjacent to the south end of the island had been ripped up, thrust over one another, and then refrozen in place, suggesting a back-and-forth motion of the

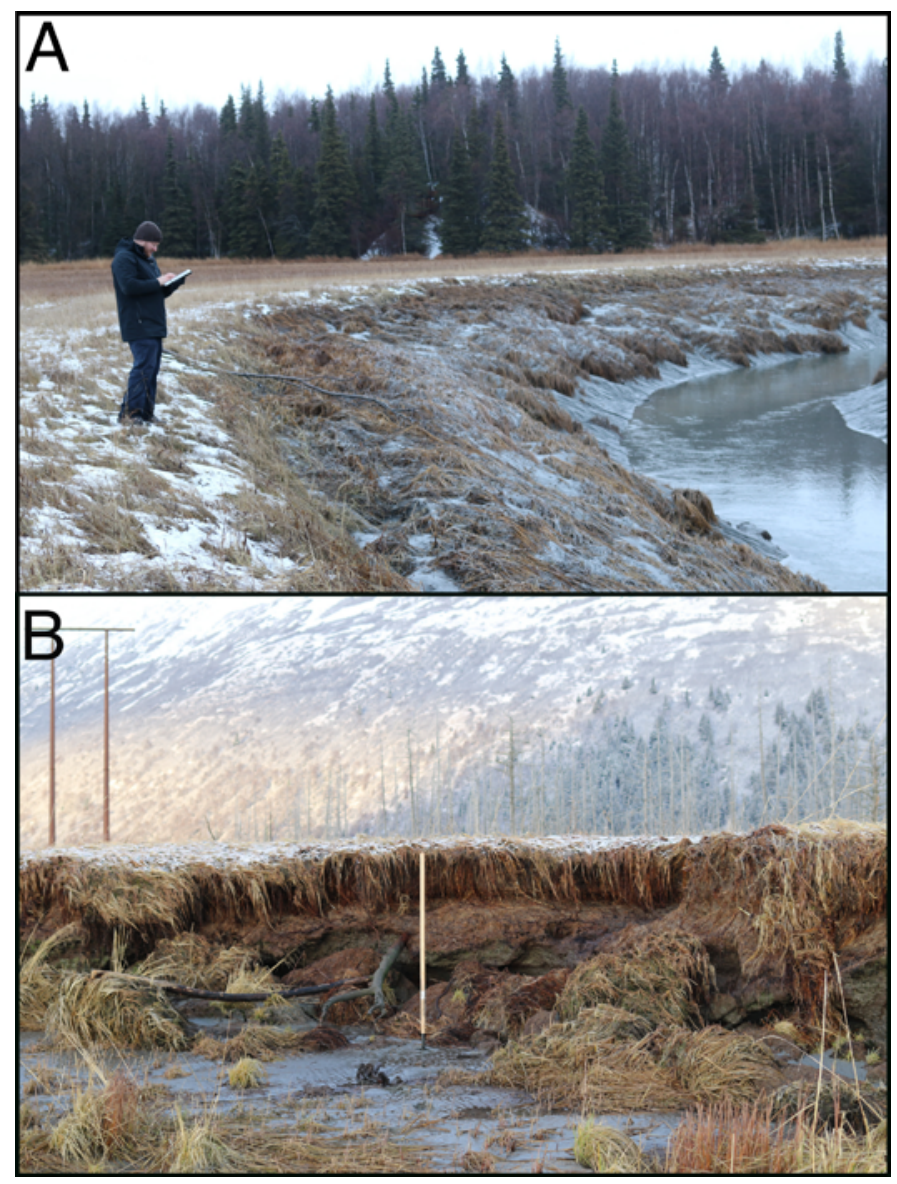

Figure 21. Photographs of examples of bank collapse following the Anchorage earthquake. $A$, Possible lateral spreading leading to partial bank collapse along lower Campbell Creek, Anchorage. Marsh grasses along the creeksides were freshly covered in soft, unfrozen muds. $B$, Bank collapse near Girdwood, Turnagain Arm. Multiple lateral spreads or bank collapses were observed within the tidal zone at this location. Locations shown in figure 4. island during the earthquake that disturbed the surrounding ice. Additionally, we noted patches of dark ice around the island and along linear fissures in lake ice north of the island. These dark patches of ice suggest that warmer water could have been released from localized sections of lake sediment during the earthquake and could have partly melted lake ice directly above. Similar observations were made in a lake on the Kenai Peninsula located south of Anchorage and Turnagain Arm.

We observed high outflows from numerous springs in the steep valleys along the north side of Turnagain Arm. Though we lack pre-earthquake baseline data to determine if this apparent uptick was a result of the earthquake, we do have confirmation from one resident of Eagle River valley that a spring near his house had dramatically increased its output since the earthquake. This suggests the earthquake might have changed the subsurface hydrology, which could influence future landslide hazard. This phenomenon also has been observed in other earthquakes (for example, Rojstaczer and Wolf, 1992; Esposito and others, 2001).

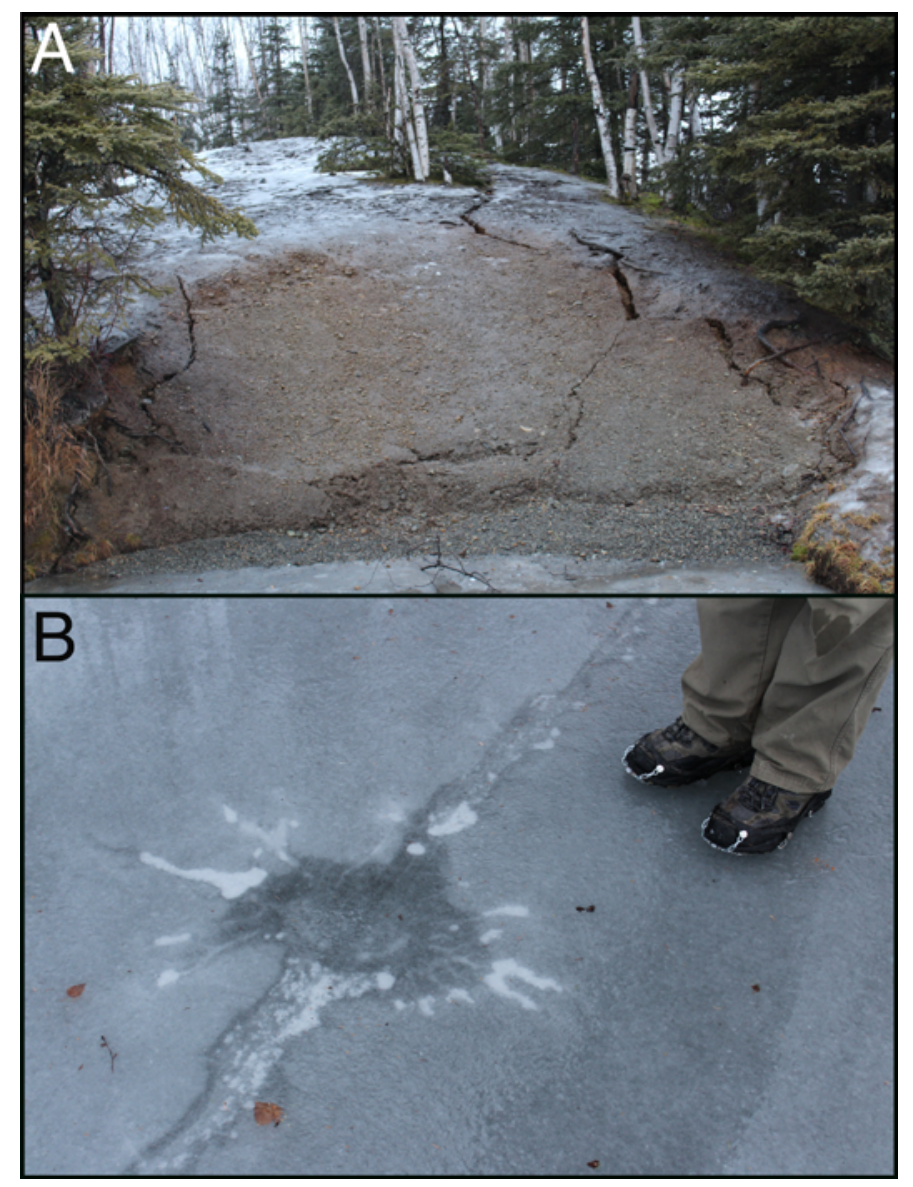

Figure 22. Photographs from Lower Fire Lake. $A$, Extensional cracks along a small island within Lower Fire Lake. $B$, Cracks in ice adjacent to the island showing clear evidence of movement and refreezing. Location shown in figure 4. 


\section{Discussion}

Previous research has related earthquake magnitude to number of triggered landslides. For the 2018 Anchorage, Alaska, earthquake investigated here (M7.1), the relation of Malamud and others (2004) predicts about 3,200 landslides; the relation of Keefer (2002) predicts about 8,200 landslides. A complete inventory of triggered landslides for this earthquake is unlikely to be produced because tree and snow cover and incomplete image availability impair visibility. Our field investigations, however, suggest that the number of landslides triggered is significantly less than the range predicted by global models, which were drawn primarily from shallow crustal earthquakes near plate boundaries that have strike-slip and reverse focal mechanisms. The relative paucity of observed ground failures following the 2018 Anchorage earthquake and similar deep, normal-fault, earthquakes without significant ground failure triggering - for example, the 2001 M6.8 Nisqually, Washington (Highland, 2003), and 2001 M7.7 El Salvador (Bommer and others, 2002) earthquakes - point to the significance of focal depth and mechanism not currently accounted for in current magnitude-landslide relations. Further consideration of earthquake depth, mechanism, and regional setting may provide improved rapid estimates of the magnitude of potential landslides in the future.

The USGS ground-failure models implicitly account for focal depth and mechanism through the ShakeMap groundmotion model, which uses ground-motion measurements, felt reports, and other factors that contribute to shaking. But the performance of the near-real-time ground-failure models was mixed. Overall, the alert levels (after the earthquake magnitude was refined from the initial $M 6.7$ to the final $M 7.1$ ) indicating that significant areas were exposed to landslide and liquefaction hazard (orange alert) agreed with our field observations. Additionally, the landslide model correctly shows the area of most concentrated landsliding around Eagle River and Peters Creek, as well as areas far up those valleys in the Chugach Mountains where we observed numerous rockfalls. The landslide model predicted scattered areas of high hazard farther south in the Chugach Mountains; what we saw was even more sparse than the model estimated, but snow cover prevented a comprehensive assessment. Landslides were triggered along the coastal bluffs surrounding Anchorage; the near real-time model did not show high hazard there, possibly related to the coarseness of the DEM ( $250 \mathrm{~m})$ or a lack of constraint of slope strength on a global scale. Although many of the areas that were affected by extensional cracking and incipient landsliding in Anchorage, Eagle River, and Peters Creek did have elevated (but low, $0.2-5$ percent) probabilities of landslide occurrence, the landslide model was not trained on this type of ground failure and underestimated the probabilities. The physically based map of Jibson and Michael (2009), which uses a much finer resolution DEM $(\sim 6 \mathrm{~m})$ but was not specific to this earthquake, did show these areas as having high seismic landslide hazard.

The near-real-time liquefaction model accurately indicated that liquefaction was likely to occur in many areas, such as along the Little Susitna River, the tidal flats of Matanuska Valley, McArthur Flats, the mouth of the Knik River, and Ingram Creek. However, we did not observe evidence of liquefaction in some areas where the model predicted high probabilities, such as the Susitna River and Chickaloon Bay, possibly because tidal erosion and snow cover hid surface evidence of liquefaction. Within Anchorage, evidence of liquefaction was observed in both locations of high predicted liquefaction hazard (probabilities of liquefaction as much as about 10 percent), such as along Chester Creek (fig. 17A) and the Port of Alaska (fig. 19D), and zones of low predicted hazard, for example, around Sand Lake (fig. 17B). Other locations, such as Campbell Creek (fig. 21A), experienced ground deformations but we were not able to conclusively determine that liquefaction occurred. Overprediction of the near-real-time models has been noted in other recent earthquakes (Allstadt and others, 2018), but underprediction in locations like Sand Lake is a new observation that merits analysis.

The location and magnitude of the minor cracking at Government Hill and Turnagain Heights indicates that the 2018 ground motion triggered minor deformation associated with 1964 landslide failure surfaces. These 1964 landslides might have amplified the shaking, as has been observed elsewhere (Hartzell and others, 2017), but no observable downslope movement of the landslide masses or remobilization occurred.

The landslides at Potter Hill (fig. 13), on the other hand, involved significant downslope movement of new landslide material as well as reactivation of parts of the 1964 landslide deposits. This area is prone to such landslides, as indicated by repeated failures caused by both earthquakes and rainfall (Hansen, 1965).

Much of the damage from this earthquake was from extensional cracking (fig. 20) that could be related to incipient landsliding, possible impedance contrasts between cut and fill parts of slopes (Stewart and others, 2001), and high levels of ground motion near the edges of steep slopes (Ashford and others, 1997). Our models do not take these phenomena into account, which clearly merit additional study.

\section{Summary}

We developed an initial inventory of ground failure features from the November 30, 2018, M7.1 Anchorage earthquake. This inventory of 153 features is from groundbased observations soon after the earthquake (December 5-10) that include the presence or absence of liquefaction, landslides, and individual crack traces of lateral spreads and incipient landslides. This is not a complete inventory and simply shows general trends and examples of types and distribution of ground failures documented. Overflight observations (December 1-6) documented landslide and liquefaction presence or absence within the Chugach Mountains and along Cook Inlet in regions inaccessible to vehicles, which greatly expanded the geographic scope of this reconnaissance. Field-mapped 
ground-failure observations have been augmented with a set of 565 georeferenced and annotated images from both field and overflight reconnaissance cataloging additional ground-failure presence or absence from the Anchorage earthquake (Grant and others, 2020).

Tidal erosion, fresh snowfall, limited daylight, and adverse flying conditions contributed significantly to the uncertainty and incompleteness of ground-failure observations during this reconnaissance. Notably, substantial liquefaction features at the mouths of the Little Susitna River (December 1) and Ingram Creek (December 5) were absent during subsequent overlapping missions (December 6 and 9, respectively) because of tidal action. A large rockfall observed on December 1 on Rainbow Peak was not observed during a subsequent December 5 overflight because of snow cover, which suggests that the general lack of observations of landsliding within the Chugach Mountains is uncertain.

Key observations include the following:

- Landslides triggered by the 1964 Alaska earthquake responded to the shaking but did not reactivate with significant downslope movement during the recent earthquake. Observed deformation is limited to extensional cracks $1-2 \mathrm{~cm}$ wide within the Turnagain Heights and Government Hill landslides.

- Most observed ground failure (landslides and liquefaction) exhibited permanent deformations of less than $\sim 20 \mathrm{~cm}$.

- A few flow slides within highway fill (most notably, Vine Road and Minnesota Drive) and glacial-marine sediment near Potter Hill produced long runout deposits and significant damage to roadways in the case of fill landslides. Slides occurred in the same location as the Potter Hill landslides that were triggered by shaking in the 1964 M9.2 Alaska earthquake.

- Widespread lateral spreading and (or) riverbank slumping was observed along lower stretches of multiple rivers and creeks along the Turnagain and Knik Arms of Cook Inlet.

- Multiple extensional cracks and possible incipient landslides that have coseismic displacements of several centimeters to a few meters occurred along Peters Creek, Eagle River, and southern Anchorage near residential dwellings.

- The 2018 earthquake produced less ground failure over a more limited area than would be predicted by present models that depend on magnitude alone. Other factors such as focal depth and mechanism probably played an important role in the relative paucity of ground failure caused by this earthquake.

- The near-real-time ground-failure models had a mixed performance. They correctly showed ground-failure concentrations in some areas, but over- or underpredicted hazard in other areas.
- Some of the locations of observed slides along the coastal bluffs were not mapped as having high landslide probability but were identified as having high liquefaction probability by ground-failure models because the resolution of the DEM could not identify these slopes. This is a good motivation to use high-resolution DEMs for the landslide model. Slope is used as a proxy for the shear-wave velocity in the upper $30 \mathrm{~m}$ of the crust $\left(V_{\mathrm{S} 30}\right)$ for liquefaction, and higher resolution slopes perform more poorly as predictors of $V_{\mathrm{S} 30}$, but a high slope at higher resolution should be effective at precluding the presence of liquefaction.

\section{References Cited}

Allstadt, K.E., Jibson, R.W., Thompson, E.M., Massey, C.I., Wald, D.J., Godt, J.W., and Rengers, F.K., 2018, Improving nearreal-time coseismic landslide models - Lessons learned from the 2016 Kaikoura, New Zealand, earthquake: Seismological Society of America Bulletin, v. 108, no. 3B, p. 1649-1664, https://doi.org/10.1785/0120170297.

Allstadt, K.E., Thompson, E.M., Hearne, M., Zhu, J., Wald, D.J., and Tanyaş, H., 2017, Integrating landslide and liquefaction hazard and loss estimates with existing USGS real-time earthquake information products, in World Conference on Earthquake Engineering, 16th, Santiago, Chile, 2017, Proceedings: Tokyo, Japan, International Association for Earthquake Engineering, paper no. 364.

Allstadt, K.E., Thompson, E.M., Wald, D.J., Hamburger, M.W., Godt, J.W., Knudsen, K.L., Jibson, R.W., Jessee, M.A., Zhu, J., Hearne, M., and Baise, L.G., 2016, USGS approach to real-time estimation of earthquake-triggered ground failure-Results of 2015 workshop: U.S. Geological Survey Open-File Report 2016-1044, 13 p., https://doi.org/10.3133/ofr20161044.

Ashford, S.A., Sitar, N., Lysmer, J., and Deng, N., 1997, Topographic effects on the seismic response of steep slopes: Seismological Society of America Bulletin, v. 87, no. 3, p. 701-709.

Bastin, S.H., Ogden, M., Wotherspoon, L.M., van Ballegooy, S., Green, R.A., and Stringer, M., 2018, Geomorphological influences on the distribution of liquefaction in the Wairau plains, New Zealand, following the 2016 Kaikōura earthquake: Seismological Society of America Bulletin, v. 108, no. 3B, p. 1683-1694, https://doi.org/10.1785/0120170248.

Bommer, J.J., Benito, M.B., Ciudad-Real, M., Lemoine, A., López-Menjívar, M.A., Madariaga, R., Mankelow, J., de Hasbun, P.M., Murphy, W., Nieto-Lovo, M., and RodríguezPineda, C.E., 2002, The El Salvador earthquakes of January and February 2001 - Context, characteristics and implications for seismic risk: Soil Dynamics and Earthquake Engineering, v. 22 , no. 5, p. 389-418, https://doi.org/10.1016/S02677261(02)00024-6. 
Combellick, R.A., 1999, Simplified geologic map and cross sections of central and east Anchorage, Alaska: Alaska Division of Geological and Geophysical Surveys Preliminary Interpretive Report 1999-1, 13 p., 2 sheets, http://doi.org/10.14509/2243.

Esposito, E., Pece, R., Porfido, S., and Tranfaglia, G., 2001, Hydrological anomalies connected to earthquakes in southern Apennines (Italy): Natural Hazards and Earth Systems Science v. 1, p. 137-144, https://doi.org/10.5194/nhess-1-137-2001.

Franke, K.W., Koehler, R.D., Beyzaei, C.Z., Cabas, A., Pierce, I., Stuedlein, A., and Yang, Z., 2019, Geotechnical Engineering Reconnaissance of the 30 November $2018 \mathrm{Mw} 7.0$ Anchorage, Alaska Earthquake: Geotechnical Extreme Events Association Report GEER-059.

Grant, A.R.R., Jibson, R.W., Allstadt, K.E., Thompson, E.M., Witter, R.C., Bender, A.M., Schmitt, R.G., 2020, Ground failure triggered by shaking during the M7 Anchorage earthquake: U.S. Geological Survey data release, https://doi.org/10.5066/ P99ONUNM.

Hansen, W.R., 1965, Effects of the earthquake of March 27, 1964, at Anchorage, Alaska: U.S. Geological Survey Professional Paper 542-A, 68 p., 2 plates, https://doi.org/10.3133/pp542A.

Hansen, W.R., Eckel, E.B., Schaem, W.E., Lyle, R.E., George, W., and Chance, G., 1966, The Alaska earthquake of March 27, 1964; field investigations and reconstruction effort: U.S. Geological Survey Professional Paper 541, 111 p., https://doi. org/10.3133/pp541.

Hartzell, S.H., Leeds, A., and Jibson, R.W., 2017, Seismic response of soft deposits due to landslide-The Mission Peak, California, landslide: Seismological Society of America Bulletin, v. 107, p. 2008-2020, https://doi. org/10.1785/0120170033.

Highland, L.M., 2003, An account of preliminary landslide damage and losses resulting from the February 28, 2001, Nisqually, Washington, earthquake: U.S. Geological Survey Open-File Report 03-211, 48 p., https://doi.org/10.3133/ ofr03211.

Jibson, R.W., Allstadt, K.E., Rengers, F.K., and Godt, J.W., 2018, Overview of the geologic effects of the November 14, 2016, $\mathrm{M}_{\mathrm{w}} 7.8$ Kaikoura, New Zealand, earthquake: U.S. Geological Survey Scientific Investigations Report 2017-5146, 39 p., https://doi.org/10.3133/sir20175146.

Jibson, R.W., and Michael, J.A., 2009, Maps showing seismic landslide hazards in Anchorage, Alaska: U.S. Geological Survey Scientific Investigations Map 3077, 2 sheets, scale 1:25,000, 11-p. pamphlet, https://pubs.er.usgs.gov/publication/ $\operatorname{sim} 3077$.

Keefer, D.K., 1984, Landslides caused by earthquakes: Geological Society of America Bulletin, v. 95, no. 4, p. 406-421, https:// doi.org/10.1130/0016-7606(1984)95\&amp;lt;406:LCBE\&amp ;gt;2.0.CO;2.
Keefer, D.K., 2002, Investigating landslides caused by earthquakes-A historical review: Surveys in Geophysics, v. 23, no. 6, p. 473-510, https://doi.org/10.1023/A:1021274710840.

Keefer, D.K., and Manson, M.W., 1998, Regional distribution and characteristics of landslides generated by the earthquake, in Keefer, D.K., ed., The Loma Prieta, California, earthquake of October 17, 1989-Landslides: U.S. Geological Survey Professional Paper 1551-C, p. C7-C32, https://doi. org/10.3133/pp1551C.

Malamud, B.D., Turcotte, D.L., Guzzetti, F., and Reichenbach, P., 2004, Landslide inventories and their statistical properties: Earth Surface Processes and Landforms, v. 29, no. 6, p. 687-711, https://doi.org/10.1002/esp.1064.

Nowicki Jessee, M.A., Hamburger, M.W., Allstadt, K.E., Wald, D.J., Robeson, S.M., Tanyaş, H., Hearne, M., and Thompson, E.M., 2018, A global empirical model for nearreal-time assessment of seismically induced landslides: Journal of Geophysical Research - Earth Surface, v. 123, p. 1835-1859, https://doi.org/10.1029/2017JF004494.

Pradel, D., Wartman, J., and Tiwari, B., 2014, Impact of anthropogenic changes on liquefaction along the Tone River during the 2011 Tohoku Earthquake: Natural Hazards Review, v. 15, p. 13-26, https://doi.org/10.1061/(ASCE) NH.1527-6996.0000097.

Rojstaczer, S., and Wolf, S., 1992, Permeability changes associated with large earthquakes-An example from Loma Prieta, California: Geology, v. 20, no. 3, p. 211-214, https:// doi.org/10.1130/0091-7613(1992)020\%3C0211:PCAWLE\% 3E2.3.CO;2.

Schmoll, H.R., and Dobrovolny, E., 1972, Generalized geologic map of Anchorage and vicinity, Alaska: U.S. Geological Survey Miscellaneous Geologic Investigations Map I-787-A, 1 sheet, scale 1:24,000, https://doi. org/10.3133/i787A.

Schmoll, H.R., Dobrovolny, E., and Gardner, C.A., 1980, Preliminary geologic map of the middle part of the Eagle River Valley, Municipality of Anchorage, Alaska, U.S. Geological Survey Open-File Report 80-890, 11 p., 1 sheet, scale 1:25,000, https://doi.org/10.3133/ofr80890.

Stewart, J.P., Bray, J.D., McMahon, D.J., and Smith, P.M., 2001, Seismic performance of hillside fills: Journal of Geotechnical and Geoenvironmental Engineering, v. 127, p. 905-919, https://doi.org/10.1061/(ASCE)10900241(2001)127:11(905).

Updike, R.G., Egan, J.A., Moriwaki, Y., Idriss, I.M., and Moses, T.L., 1988, A model for earthquake-induced translatory landslides in Quaternary sediments: Geological Society of America Bulletin, v. 100, p. 783-792, https://doi. org/10.1130/0016-7606(1988)100\%3C0783:AMFEIT\%3E2 .3. $\mathrm{CO} ; 2$. 
Varnes, D.J., 1978, Slope movement types and processes, in Schuster, R.L., and Krizek, R.J., eds., Landslides-Analysis and control: Washington, D.C., Transportation Research Board Special Report 176, p. 11-33.

Wald, D.J., Jaiswal, K.S., Marano, K.D., Bausch, D.B., and Hearne, M.G., 2010, PAGER - Rapid assessment of an earthquake's impact: U.S. Geological Survey Fact Sheet 2010-3036, 4 p. [revised November 2011].
Worden, C.B., and Wald, D.J., 2016, ShakeMap Manual OnlineTechnical Manual, User's Guide, and Software Guide: U.S. Geological Survey online manual, https://doi.org/10.5066/ F7D21VPQ.

Zhu, J., Baise, L.G., and Thompson, E.M., 2017, An updated geospatial liquefaction model for global application: Seismological Society of America Bulletin, v. 107, p. 1365-1385, https://doi. org/10.1193/121912EQS353M. 


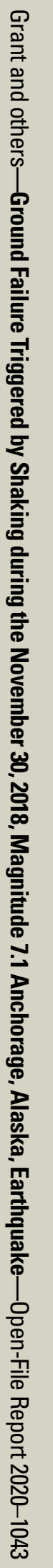

